IZA DP No. 4459

Asabiyya:

Re-Interpreting Value Change in Globalized Societies

Arno Tausch

Almas Heshmati

September 2009 


\title{
Asabiyya: Re-Interpreting Value Change in Globalized Societies
}

\author{
Arno Tausch \\ Innsbruck University
}

Almas Heshmati
Seoul National University
and IZA

Discussion Paper No. 4459

September 2009

IZA

P.O. Box 7240

53072 Bonn

Germany

Phone: +49-228-3894-0

Fax: +49-228-3894-180

E-mail: iza@iza.org

Any opinions expressed here are those of the author(s) and not those of IZA. Research published in this series may include views on policy, but the institute itself takes no institutional policy positions.

The Institute for the Study of Labor (IZA) in Bonn is a local and virtual international research center and a place of communication between science, politics and business. IZA is an independent nonprofit organization supported by Deutsche Post Foundation. The center is associated with the University of Bonn and offers a stimulating research environment through its international network, workshops and conferences, data service, project support, research visits and doctoral program. IZA engages in (i) original and internationally competitive research in all fields of labor economics, (ii) development of policy concepts, and (iii) dissemination of research results and concepts to the interested public.

IZA Discussion Papers often represent preliminary work and are circulated to encourage discussion. Citation of such a paper should account for its provisional character. A revised version may be available directly from the author. 
IZA Discussion Paper No. 4459

September 2009

\section{ABSTRACT \\ Asabiyya: Re-Interpreting Value Change in Globalized Societies}

This article reflects the renewed interest of economics and the social science discipline in value systems and religion. The World Values Survey provided a data framework of global value change, whose quantitative results led Barro (2004) to analyze the connections between some dimensions of recent sociological religious value research with economic growth. The present essay starts from this methodological position, and links value systems with economic performance in a much wider and macrosociological framework. We further develop the well-known Inglehart and Welzel (2003) map of global values, and develop the idea of "Asabiyya" ("social cohesion"), as a counter-model to both Barro and Inglehart and Welzel approaches. A frequently asked question is whether "modernization" without "spiritual values" in a globalized world economy and world society possible in the long run? Starting from principal component analysis, it is shown that rather two factors are decisive in understanding global value change: a continuum of "traditional versus secular", and a continuum "cheating versus active society". Asabiyya in the $21^{\text {st }}$ Century, as a way out from the modernization trap of societies, characterized by large-scale social anomaly, is a high secularism combined with a high active society score, thus avoiding the "modernization trap". We show that economic growth in the current world crisis is far more connected with these dimensions. We conclude that not a society based on fear is needed in the first place, but an active society of volunteer social work.

JEL Classification: $\quad$ C43, F5, Z12, D73

Keywords: index numbers and aggregation, international political economy, religion, bureaucracy, corruption

Corresponding author:

Almas Heshmati

TEMEP \#37-306, College of Engineering

Seoul National University

San 56-1, Shilim-dong, Kwanak-Gu

Seoul, 151-742

South Korea

E-mail: heshmati@snu.ac.kr 


\section{Introduction}

This article reflects the renewed interest of economics and the social science disciplines in general in value systems and religion. Barro (2004), Barro and McCleary (2004) already paved the way for such an analysis by showing the connections between some dimensions of recent sociological religious value research with economic growth.

The World Values Survey provided a data framework of global value change, whose quantitative results led members of the economic profession, most notably, Barro, 2004 to analyze the connections between some dimensions of recent sociological religious value research (like the strength of the belief in hell) with economic growth. The present essay starts from this methodological position, and, like Barro links value systems with economic performance. The belief in or the fear of hell is part and parcel of a larger set of traditional values. With the free available country-wide data from the World Values Survey, we re-interpret Barro's thesis in a much wider and macrosociological framework. We further develop the well-known Inglehart and Welzel (2003) map of global values, and develop the idea of "Asabiyya" ("social cohesion"), inherent in classic Arab historiography, first described by Ibn Khaldun (1332 to 1406) in his work "Muqaddimah", as a counter-model to both Barro (20030 and Inglehart and Welzel (2003).

A frequently asked question is whether "modernization" without "spiritual values" in a globalized world economy and world society possible in the long run? Starting from our multivariate analysis of the World Values Survey data (principal component analysis), it is shown that rather two factors are decisive in understanding global value change: a continuum of "traditional versus secular", and a continuum "cheating versus active society". Asabiyya is defined then empirically by the residuals from the two factor scores. Asabiyya in the $21^{\text {st }}$ Century, as a way out from the modernization trap of societies, characterized by large-scale social anomaly, is a high secularism combined with a high active society score, thus avoiding the "modernization trap" of an increasingly secular society, which accepts cheating on taxes; accepts government benefits fraud and taking bribes. This re-discovery of the "active society paradigm", inherent in Etzioni's sociological theory, for cross-national research on religion and economic growth also shows that the "active society" of volunteer organization work is the best societal medicine against this kind of value decay, which is so common, according to our study, in countries like France, Brazil, or most of East Central Europe and the former USSR.

An active form of religious or non-religious humanism, which provides a noble motivation for such activities as volunteer social services, is a very necessary precondition for social cohesion in the $21^{\text {st }}$ Century. Finally, we show on the basis of these data and with very recent IMF data and prognoses (2009) about economic growth in the world system for 2009 and 2010 that economic growth in the current world crisis is far more connected with these dimensions than with the belief in hell, as stipulated by Barro. We also control for the negative effects of Kearney's globalization index on current and future economic growth in our equations. We conclude that not a society based on fear is needed in the first place, but an active society of volunteer social work.

Rest of this study is organized as follws. After presenting an overview of contemporary quantitative and comparative value research, "Asabiyya" is developed as a countermodel to both Barro and Inglehart/Welzel. Principal component analysis is used to 
identy factors which are decisive in understanding global value change. Using IMF data and prognoses we investigate the connection between economic growth these dimensions. We also control for the negative effects of globalization index on current and future economic growth in our equations. Conclusions finalize the article.

\section{Making use of the "World Values Survey" data}

This study thus uses an array of quantitative methods to come to terms with global values, global value change and current economic depression or growth. To be sure, especially the contemporary debate about "Islam" in globalized society lacks the empirical, sociological data which urgently would be required to study "the realities on the ground". ${ }^{1}$ As we shall analyze in this article, economic growth with a vengeance currently shifts to non-western regions of the world economy, thus falsifying the pessimistic prognoses by Huntington (1996) on the incompatibility of Muslim culture with economic growth.

But a silent and behavioural revolution and quantitative indicator research are beginning to be firmly established in the evolving debate about "global values". Robert Barro $^{2}$, Ronald T. Inglehart ${ }^{3}$, Jytte Klausen ${ }^{4}$, Dalia Mogahed ${ }^{5}$, Mansoor Moaddel ${ }^{6}$, Marcus Noland ${ }^{7}$, Pippa Norris ${ }^{8}$, and Thorleif Pettersson ${ }^{9}$ introduced the necessary

\footnotetext{
${ }^{1}$ For a selection of related studies see: Abdullah and Khoury, 1984; Amin, 1989; Armstrong 1993, 2000, 2006; Aydin 2003; Balic, 2001; Bardakoglu, 2006; Berger, 2001; Boff, 2005; Bsteh 1996; Bsteh and Anawati, 1978; Bsteh and Dupré, 2007; Bsteh and Khoury, 1994; Erdenir 2006; Huntington, 1996; Khoury 1980, 1991, 1994, 2001, 2002, 2005, 2007a, 2007b, 2008a, 2008b; Khoury et al., 2006; Lewis, 1993, 2002, 2003; Tibi B., 1973, 1981, 1985, 1990, 1992a, 1992b, 1995, 1996, 1997, 1997a, 1997b, 1998a, 1998b, 2000, 2001a, 2001b, 2001b, 2002, 2007; Troll 1978, 2001a, 2001b, 2003, 2004, 2007; Troll and Bsteh, 1997; Troll and Donohue, 1998; Troll and Vahiduddin, 1986.

${ }^{2}$ Religion and economic growth / (together Rachel M McCleary), Cambridge, Mass.: National Bureau of Economic Research, 2003.

${ }^{3}$ Islam, gender, culture, and democracy: findings from the World Values Survey and the European Values Survey / Willowdale, ON: De Sitter Publications, 2002, and Islam \& the West: testing the clash of civilizations thesis / (gemeinsam mit Pippa Norris), Cambridge, Mass.: Research Programs, John F. Kennedy School of Government, Harvard University, 2002.

${ }^{4}$ The Islamic challenge: politics and religion in Western Europe / New York, N.Y.: Oxford University Press, 2005; Continuity and change in contemporary capitalism / Cambridge, UK; New York, NY: Cambridge University Press, 1999; War and welfare: Europe and the United States, 1945 to the present / New York: St. Martin's Press, 1998; European integration in social and historical perspective: 1850 to the present / Lanham, Md.: Rowman \& Littlefield Publishers, 1997; Has liberalism failed women?: assuring equal representation in Europe and the United States / New York, N.Y.: PALGRAVE, 2001

${ }^{5}$ Who Speaks for Islam?: What a Billion Muslims Really Think. By John L. Esposito, Dalia Mogahed, March 2008, New York: Gallup Press.

${ }^{6}$ Class, politics, and ideology in the Iranian revolution / Columbia University Press, 1993; The Oxford handbook of global religions / (with Juergensmeyer, Mark) Oxford; New York: Oxford University Press, 2006; Modernist and fundamentalist debates in Islam: a reader / New York: Palgrave Macmillan, 2002, 2000; Islamic modernism, nationalism, and fundamentalism: episode and discourse / Chicago: University of Chicago Press, 2005; Jordanian exceptionalism: a comparative analysis of state-religion relationships in Egypt, Iran, Jordan, and Syria / Houndmills, Basingstoke, Hampshire; New York: Palgrave, 2002; Values and perceptions of the Islamic and Middle Eastern publics / New York: Palgrave Macmillan, 2007

7 The Arab economies in a changing world / (with Howard Pack), Washington, DC: Peterson Institute for International Economics, 2007.

${ }^{8}$ Sacred and secular: religion and politics worldwide / Pippa Norris; Ronald Inglehart; Cambridge, UK; New York: Cambridge University Press, 2004.

${ }^{9}$ Measuring and mapping cultures: 25 years of comparative value surveys / Leiden; Boston: Brill, 2007; The retention of religious experiences / Uppsala: [Univ.]; Stockholm: distr., Almqvist \& Wiksell international, 1975 und Scandinavian values: religion and morality in the Nordic countries / Uppsala: S. Academiae Ubsaliensis; Stockholm: Distributor, Almqvist \& Wiksell International, 1994. Also, his path-breaking article "The Religious Factor in Contemporary Society: The Differential Impact of Religion on the Private and Public Sphere in
} 
empirical elements into a value-loaded debate, otherwise still often characterized by such terms as "leading culture" or "guiding culture", especially in Europe. Professor Bassam Tibi, one of the most important authorities on Islam, world-wide, said in an interview with Der Spiegel:

"I have always emphasized how dangerous it is to talk about a specifically German Leitkultur. [...] The important thing is: the line doesn't run between Europe and Islam, but between all open societies and their enemies. I myself am Muslim and I stand on the side of an open society. Democratic Muslims like myself can push for a European Leitkultur and against its enemies. [...]My idea of a European Leitkultur is based on the foundation of a democratic community whose members are bound together through a collective identity as citizens of that community. Such a collective identity -- in the sense of the French Citoyenite (citizenship) -- stands above religious identity. Religion may, of course, be practiced privately, but in public only citizenship counts. Such a concept would unite Muslims with non-Muslims. [...] In my understanding [...] multiculturalism means "anything goes." [...] The better concept would be cultural pluralism. Unlike multiculturalism, cultural pluralism doesn't just mean diversity but also togetherness -- primarily the understanding of the rules of the game -- the European values structure. (http://www.spiegel.de/international/0,1518,329784,00.html)

Certainly, there was also a recent upsurge of research on such phenomena as Muslim values, and the relationship of Muslim values to economic growth and the structures of international inequality. ${ }^{10}$ The World Values Survey data, freely available on the Internet (http://www.worldvaluessurvey.org/), now focus on over 80 countries, covering almost $90 \%$ of global population. The sociological and political science approach, underlying the project, asks global respondents since the mid-1980s the same kind of questions, like:

Qualities that children can be encouraged to learn at home

Important child qualities: good manners(A027)

Important child qualities: independence(A029)

Important child qualities: hard work(A030)

Important child qualities: feeling of responsibility(A032)

Important child qualities: imagination(A034)

Important child qualities: tolerance and respect for other people(A035)

Important child qualities: thrift saving money and things(A038)

Important child qualities: determination perseverance(A039)

Important child qualities: religious faith(A040)

Important child qualities: unselfishness(A041)

Important child qualities: obedience(A042)

The hundreds of questions, available to users of the WVS website, are grouped into the following nine categories, and also form the empirical basis for this article. The survey

Comparative Perspective" (together with Halman, Loek; and Verweij, Johan) in International journal of comparative sociology. 40, no. 1, (1999): 141ff. has to be duly mentioned here

${ }^{10}$ See BM.I.SIAK, 2006; Diez-Nicolás, 2007; Dittrich, 2006; Donno and Russett, 2004; HUDSON Institute, 2006; Inglehart 2007; Inglehart and Norris, 2003; Jabber, 2001; Noland, 2004; 2005; Noland and Pack, 2004; Norris and Inglehart, 2004; Pettersson 2007; PEW Research Center, 2006; RAND Corporation, 2005, 2006; Savage, 2004; Weede, 2006. 
cover the time periods 1981-1984, 1989-1993, 1994-1999, and 1999-2004 (the socalled “waves” of the World Values Survey):

1. Structure

2. Perceptions of life

3. Environment

4. Work

5. Family

6. Politics and Society

7. Religion and Morale

8. National Identity

9. Sociodemographics

\section{Index construction}

The cross-national opinion data from the World Values Survey render themselves for further analytical index construction. Recently, social science research took up again the question of complex indicator formation (Heshmati, 2006; Heshmati and Oh, 2006, Heshmati, Tausch and Bajalan, 2008). This work was first developed in the field of human development, globalization indices, child welfare indices and European Union Lisbon agenda or Lisbon process indices. Outcomes and opinion structures are often multidimensional and represented by several indicators with both positive and negative effects. However, here the objective is not to evaluate the effects of certain policy programs, but rather to quantify the state of the outcome or opinion structures. The multidimensionality of the outcome or opinion structures requires the creation of composite indices to have a single measure and also to aggregate the indicators. On the basis of the "World Values Survey" data, which are multidimensional and decomposable, such indices will be useful tools in the quantification of the state of global opinion and values and the evaluation of their impacts on development. In this section, we introduce two approaches -non-parametric and parametric indices, - used here in the construction of such indices, based on the World Values Survey.

\section{Non-parametric index}

A non-parametric index is a composite index constructed such as to aggregate a number of indicators of a certain process, opinion structure or outcome. Such indices are used in the social science literature for the measurement of globalization (Heshmati, 2006; Andersen and Herbertsson, 2003; Kearney, 2002 and 2003; Lockwood, 2004;), environment (Kang, 2002), human development (Noorbakhsh, 1998), development strategy, technology and research (Heshmati and Oh, 2006; Archibugi and Coco, 2004), or other types of indices (Inglehart, 1990; Inglehart and Norris, 2003; Norris and Inglehart, 2004). For instance, the well-known "globalization index" is a simple combination of forces driving the integration of ideas, people, and economies, worldwide. It is composed of four major components: economic integration, personal contact, internet technology, and political engagement, each being generated from a number of determinant variables. Such an index can also serve as a model for the computation of a volunteer index or other indices - as the ones developed in this article - on the basis of the "World Values Survey" data. 
In the recently debated case of child well-being (Heshmati, Tausch and Bajalan, 2008), the index was composed of six components: material well-being, health and safety, educational well-being, peers and family relationships, behaviours and risk, and social well-being. The CWI - child-well-being index - was then estimated parametrically or computed non-parametrically based on the normalization of the child well-being indicators and their subsequent aggregation, using an ad hoc weighting system as follows:

$$
C W I_{t}=\sum_{j=1}^{J} \sum_{m=1}^{M} \omega_{j m}\left\{\left(X_{j m i}-X_{j m}^{\min }\right) /\left(X_{j m}^{\max }-X_{j m}^{\min }\right)\right\}
$$

where $i$ and indicate country; $m$ and $j$ are within and between component variables; $\omega_{j m}$ are the weights attached to each contributing $X$-variable within a component and weights attached to each of the six components; and min and max are minimum and maximum values of respective variables across countries in a given year. Such indices are similar to the commonly-used index, the United Nations Human Development Index (HDI), which is based on educational attainment, life expectancy and real GDP per capita. ${ }^{11}$

An index of type (1) is suitable for indicators with an expected positive effect on World Values Survey aggregates, constructed from WVS data. In cases where the indicators are expected to have a negative impact on WVS aggregate indices, the corresponding index is written as:

$$
C W I_{i}=\sum_{j=1}^{J} \sum_{m=1}^{M} \omega_{j m}\left\{\left(X_{j m}^{\max }-X_{j m i}\right) /\left(X_{j m}^{\max }-X_{j m}^{\min }\right)\right\}
$$

where the two indices differ only by the nominator of the ratio. Alternatively, prior to the normalization in (1) and aggregation, the negative indicators are transformed to inverses, $(1 / X)$ reversing their expected impact from negative to positive.

The index component's weights in equations (1) and (2) are chosen on an ad hoc basis and are constant across countries. However, this non-parametric index can be also used as a benchmark index. Lockwood (2004), in computation of a globalization index, finds the ranking of countries to be sensitive to the way the indicators are measured, normalized and weighted.

\section{Parametric index}

There are at least two other alternatives, but parametric approaches to the nonparametric index above for computing opinion indices or behaviour indices; using the principal component (PC) or factor analysis (FA) approach (for recent applications see Andersen and Herbertsson, 2003). ${ }^{12}$ In this study we adopt the PC approach. Since the two methods in normalized form give PC scores with unit variance, we use only the PC results in the analysis of World Values Survey indicators. It is used to measure global

\footnotetext{
${ }^{11}$ For a review of the HDI, its components, criticisms on the index, alternative measures and suggestions for some improvements of the index, see Noorbakhsh (1998).

${ }^{12}$ For recent surveys on the literature on the use of composite indices in different development research context, see also Archibugi and Coco (2004).
} 
values and attribute it to the possible underlying sources of global values. PC analysis was originated by Pearson (1901) and further developed by Hotelling (1933).

Principal component analysis is a multivariate technique for examining relationships within a set of interrelated quantitative variables. Given a dataset with $\mathrm{J}$ numeric indicators, at most $\mathrm{P}$ principal components can be computed; each is a linear combination of the original indicators with coefficients equal to the eigenvectors of the correlation of the covariance matrix. The principal components are sorted according to the descending order of the Eigenvalues, which are equal to the variance of the components. In short, PC analysis can be viewed as a way to uncover approximate linear dependencies among variables. This method gives a least square solution to the following model:

$$
Y=X B+E
$$

where $Y$ is a $n \times p$ matrix of the centred observed variables, $X$ is the $n \times j$ matrix of scores of the first $j$ principal components, $B$ is a $j \times p$ matrix of eigenvectors or factor patterns, $E$ is a $n \times p$ matrix of residuals, $n$ is the number of observations, $p$ the number of partial variables, and $j$ the number of variables or indicators of strategy. Unlike in a traditional least squares estimation method case, where the vertical distance to the fitted line is minimized, here the sum of the squared residuals measured as distances from the point to the first principal axis.

\section{The Inglehart worldview}

Inglehart/Welzel, 2003, came up with the up to now most plausible and also empirically well founded scheme of global value development and measurement. The transition of countries from traditional to modern societies grouped by combination of scales of self expression and survival and secular-rational and traditional values according to Inglehart is reported in Graph 1:

Graph 1: The transition from traditional to modern societies, according to Inglehart

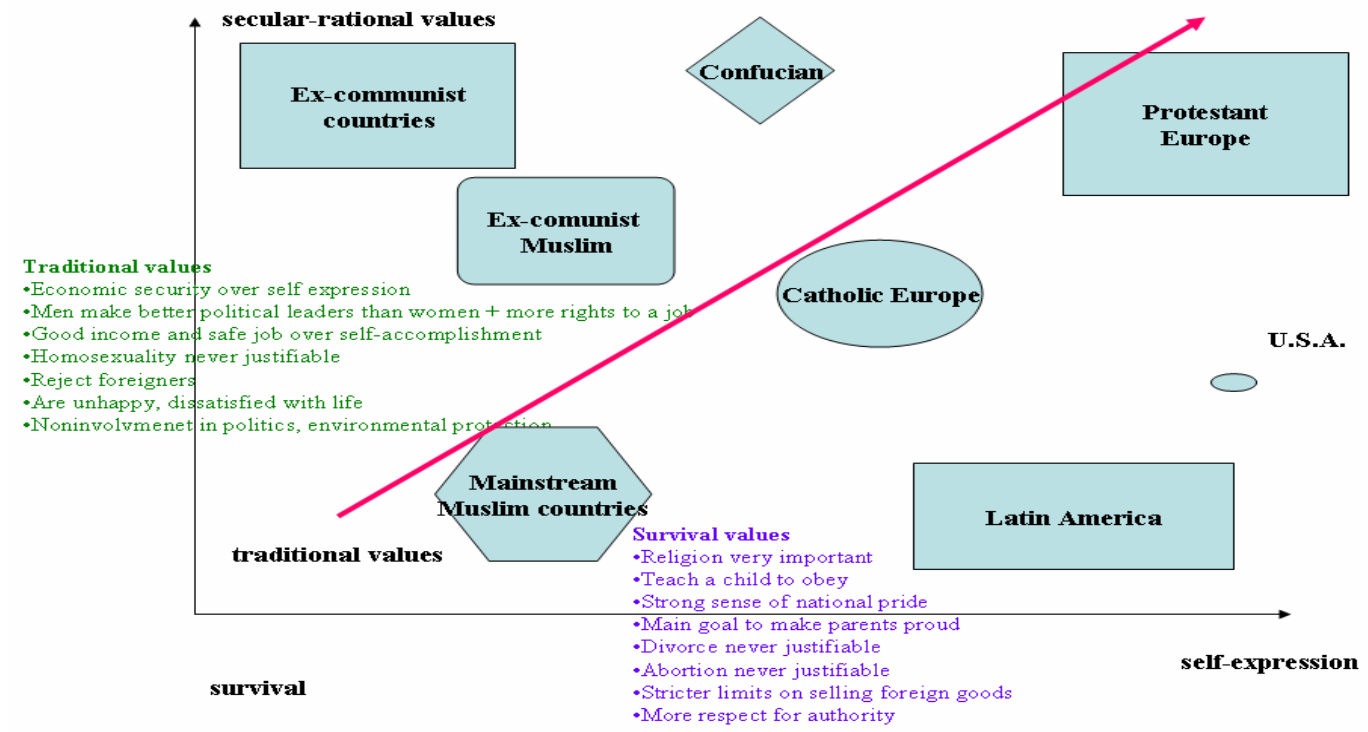


Note: our own compilations on the basis of Inglehart/Welzel, 2003. Inglehart/Welzel factor-analyzed the WVS-country results for the variables: Abortion never justifiable; Divorce never justifiable; Main goal to make parents proud; More respect for authority; Religion very important; Stricter limits on selling foreign goods; Strong sense of national pride; Teach a child to obey and drew the conclusion that the resulting principal component represents survival versus self expression. Likewise, he factor-analyzed the country results for the WVS variables: Are unhappy, dissatisfied with life; Economic security over self expression; Good income and safe job over self-accomplishment; Homosexuality never justifiable; Men make better political leaders than women + more rights to a job; Non-involvement in politics, environmental protection; Reject foreigners and drew the conclusion that this dimension represents the "traditional versus secular".

One of the most famous pieces of Inglehart's research tradition is the Inglehart/Welzel, 2003 world map of human values, which depicts the trajectory of all the countries of the world both over space and time. Starting from the left-hand lower corner, a society, as a rule, will move to the upper right hand corner of Graph 2. This sociological "law", which was obtained by the statistical mathematical model of principal component analysis, based on the WVS data, must be regarded as one of the most solidly based observations of sociological theory today.

Graph 2: The Inglehart-Welzel, 2003 map of global values

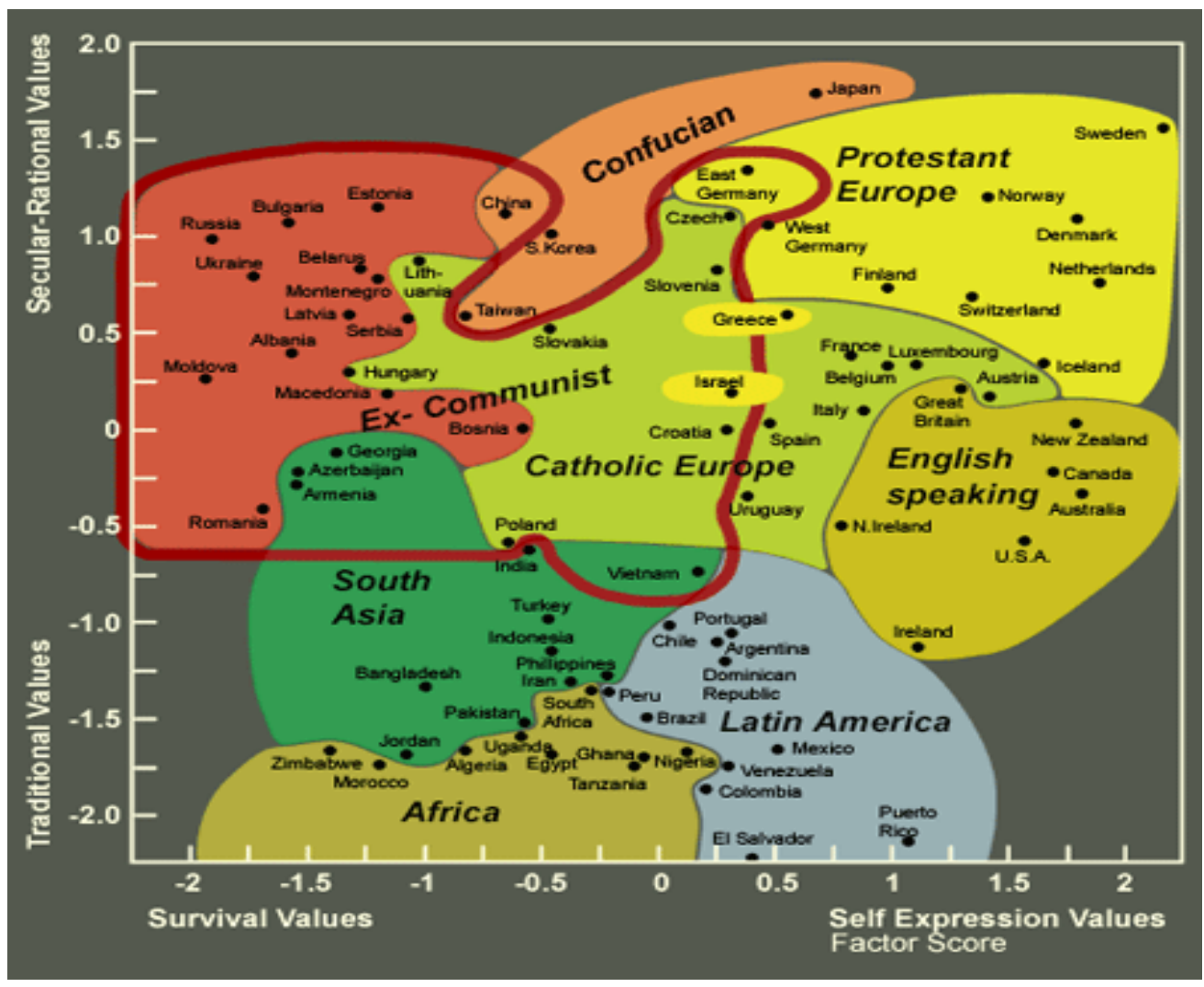

Source: http://www.worldvaluessurvey.org/

Note: based on Inglehart/Welzel. The authors would assume that societies do move along the global path, symbolized by the arrow, from a traditional and survival oriented value set towards a secular and selfexpression oriented value set. 


\section{The Ibn Khaldoun counter-model}

But what can we say about the outliers? The classic Arab historian and philosopher Ibn Khaldun (1332-1406) (Ibn Khaldoun, 2005), explained in his most important book "Muqaddimah" (Introduction to history) [see also Tibi, 1996] that historical change and the succession of dynasties are a function of the interactions between nomadic culture and urban civilization.

His major contribution in this context then consisted in the analysis of the correlation between 'Asabiyya', the social cohesion of a society, and political power. He argued that the strong social cohesion of tribal peoples enabled them to conquer urbanized regions and build regimes and civilizations, but that these conquests were undone by the tribes' gradual loss of 'Asabiyya' in the urban setting, leading to new conquests by tribal peoples still strong in desert cohesiveness. Although power was the basis of rulership and royal authority was established through military might, the "glue" that held societies together (Tibi, 1996) was 'Asabiyya', based on kinship and religion and stronger in tribal than in urban society. Conquerors, whose social cohesion was weak were soon overcome by the civilization of the conquered and gave way to a new conquering group. Rulers would be successful only so long as they remained just; as the rulers' level of luxury increased, so did their level of exploitation, and injustice soon produced division and "the ruin of civilization" (Tibi 1996). Ibn Khaldun also foresaw the tendency towards economic cycles, which he linked, quite in a modern fashion, to this “value change” (Inglehart/Norris, 2003; Norris/Inglehart, 2004).

Contemporary quantitative Kondratiev cycle researchers, like Rennstich, 2007, stumbled onto the issue again, without duly taking into account the theoretical forerunner Ibn Khaldoun and linking the four generation cycle to the Nobel-laureate winning four generation family sage "Buddenbrooks. The Decline of a family" by the German novelist Thomas Mann (Mann, 1924), and calling the four-generation cycle the Buddenbrooks cycle. According to the Buddenbrooks cycle school the novel by Thomas Mann contains a dire and general message for societal systems and is a model of analysis, also to be applied to the contemporary, post-World-War II world order. Independently of Rennstich, Devezas/Corredine, already in 2001, developed a similar and mathematical model, also based on the four-generation "model". Schumpeter, in his rather conservative and pessimistic interpretation, also touched upon this issue in his 1950 "Capitalism, Socialism and Democracy", when he stated that capitalism will not disappear from the face of the earth by a socialist revolution, but by the gradual erosion of capitalist individual family values and the rise of a socialist-oriented intellectual elite and bureaucracy.

In terms of modern social science theory, the following Khaldounian scheme can be proposed. Societies do not generally experience a smooth transformation from a traditional and survival oriented value set towards a secular and self-expression oriented value set. The "Asabiyya" based counter-model to Inglehart relies on a factor analytical evaluation of the following variables in the World Values Survey, and combines theoretical insights of the Inglehart School with those by Amitai Etzioni.

At the very beginning of the modernization process, societies are traditional, religious, and pre-modern; but at the same time they are also "active" societies with functioning neighbourhood structures, and very clear perceptions of what are "good" and "evil", and a high respect of the law. As the modernization process proceeds, traditional 
religious values seem to be on the losing side of the societal equation. The uneasiness of the "religious right" in the United States, of the Islamist camp in many countries of the Muslim world, and the religious right in many developing countries is best understood by the process, whereby traditional values get lost at the same time with dimensions of the active society and respect of the law in such vital areas as tax morale, non-acceptability of bribery and government benefits fraud.

Islamists are of course wrong in assuming that countries of the Muslim world are the only ones to suffer from a downward trend in public morale. The worst global performers according to our data based on the Inglehart/Etzioni synthesis shown in Graph 3, it seems, are Belarus, Brazil, Slovakia, and the Ukraine. As churches and religious temples of all denominations are empty in the West and the Orthodox East, so are the volunteer organizations; and since "God" does not "exist", everything becomes feasible, acceptable, and even becomes practice: cheating taxes, taking bribes, receiving government benefits even if you are not entitled for them:

Graph 3: The Inglehart/Etzioni synthesis

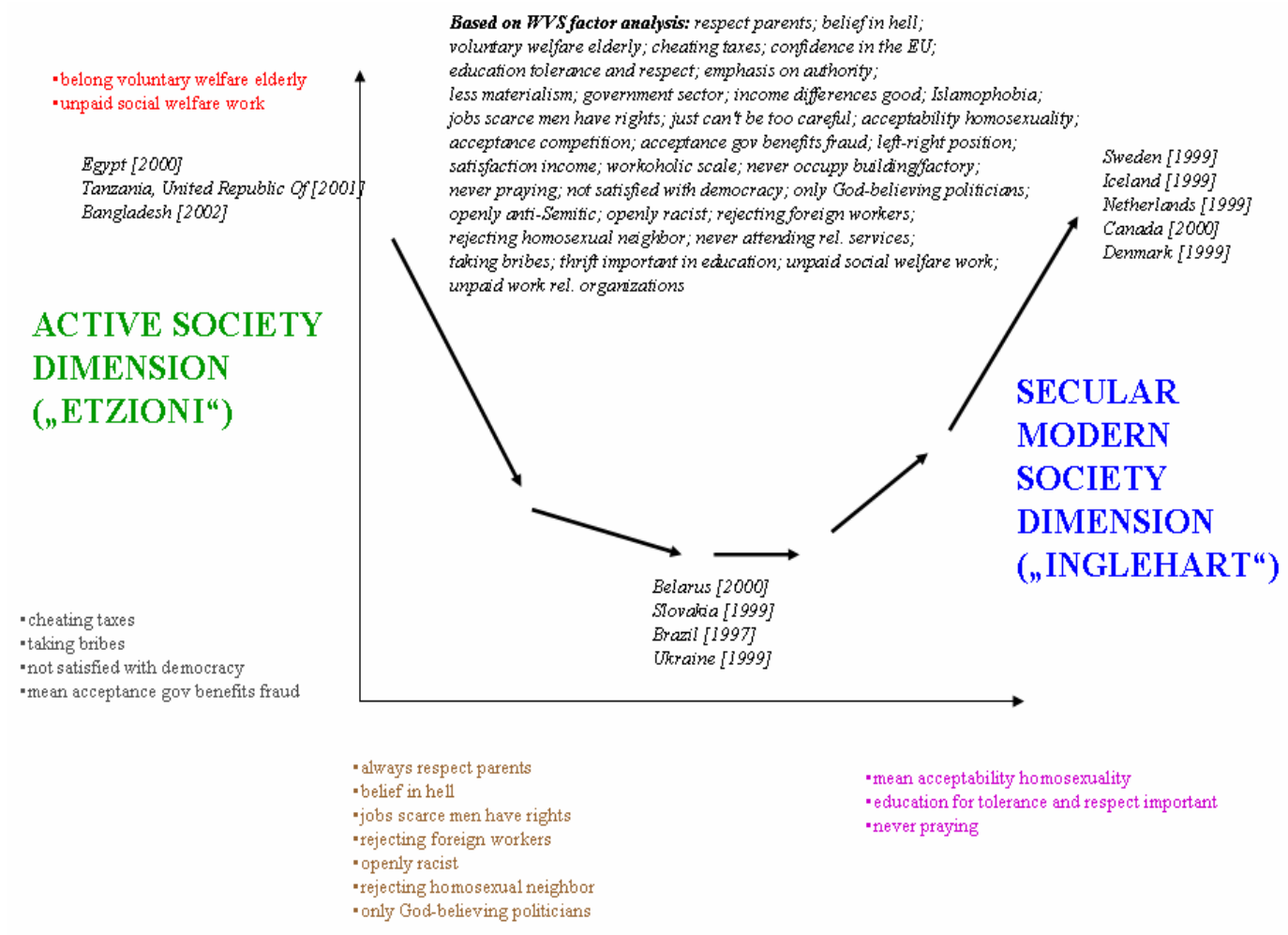

Factor loadings $>0.5$; two factors extracted

Note: our own calculations and compilations, based on the World Values Survey data, wave $3+4$. The following WVS country values were submitted to an explorative principal component analysis: always respect parents; belief in hell; cheating taxes; education for tolerance and respect important; jobs scarce men have rights; mean acceptability homosexuality; mean acceptance government benefits fraud; never praying; not satisfied with democracy; only God-believing politicians; openly racist; rejecting foreign workers; rejecting homosexual neighbour, belong voluntary welfare elderly; taking bribes; unpaid social welfare work. Our analysis yielded two factors: a continuum of "traditional versus secular", and a continuum ,cheating versus active society“. 


\section{Principal components results}

A full lits of the WVS variables is found in Appendix A and the data sources in Appendix B. Our parametric principal component analysis of the country values from the WVS is shown in Table 1. The detailed information about the factor loadings and score is found in Appendix C. The logic of global value change yields the following results:

Table 1: The logic of global value change - results from a principal component analysis of the WVS data

\begin{tabular}{|c|c|c|}
\hline & $\begin{array}{c}\text { traditional versus secular } \\
\text { attitudes }\end{array}$ & $\begin{array}{l}\text { cheating versus active } \\
\text { society }\end{array}$ \\
\hline Albania [2002] & 0,98230 & 0,43260 \\
\hline Algeria [2002] & 1,45209 & $-0,49094$ \\
\hline Argentina [1999] & $-0,44307$ & $-0,05472$ \\
\hline Armenia [1997] & 0,77980 & 1,66401 \\
\hline Australia [1995] & $-0,93678$ & $-0,76537$ \\
\hline Austria [1999] & $-0,97091$ & $-0,07798$ \\
\hline Azerbaijan [1997] & 0,61006 & 1,19167 \\
\hline Bangladesh [2002] & 2,18350 & $-2,99290$ \\
\hline Belarus [2000] & $-0,21767$ & 1,97288 \\
\hline Belgium [1999] & $-1,23220$ & 0,49300 \\
\hline Bosnia and Herzegovina [2001] & 0,31595 & 0,42056 \\
\hline Brazil [1997] & 0,07281 & 1,59396 \\
\hline Bulgaria [1999] & 0,14131 & 0,55246 \\
\hline Canada [2000] & $-1,17932$ & $-1,15722$ \\
\hline Chile [2000] & $-0,42296$ & 0,39903 \\
\hline China [2001] & 0,45827 & $-1,50132$ \\
\hline Colombia [1998] & 0,13339 & $-0,32860$ \\
\hline Croatia [1999] & $-0,07525$ & 0,58302 \\
\hline Czech Republic [1999] & $-0,99273$ & 0,22380 \\
\hline Denmark [1999] & $-2,15271$ & $-1,02601$ \\
\hline Dominican Republic [1996] & 0,23134 & $-0,37255$ \\
\hline Egypt [2000] & 1,55878 & $-1,80361$ \\
\hline El Salvador [1999] & 0,86786 & 0,06298 \\
\hline Estonia [1999] & $-0,62562$ & 1,18742 \\
\hline Finland [2000] & $-1,35510$ & $-0,61301$ \\
\hline France [1999] & $-1,60311$ & 0,79870 \\
\hline Georgia [1996] & 0,90504 & 0,83050 \\
\hline Germany West [1999] & $-1,38045$ & $-0,11204$ \\
\hline Great Britain [1999] & $-1,20566$ & $-0,26451$ \\
\hline Greece [1999] & $-0,75721$ & 1,02687 \\
\hline Hungary [1999] & $-0,15168$ & 0,82649 \\
\hline Iceland [1999] & $-1,64298$ & $-1,34893$ \\
\hline
\end{tabular}




\begin{tabular}{|c|c|c|}
\hline India [2001] & 0,79819 & $-0,16288$ \\
\hline Indonesia [2001] & 1,32012 & $-0,45486$ \\
\hline Iran (Islamic Republic of) [2000] & 0,54234 & $-0,72874$ \\
\hline Iraq [2004] & 0,95986 & $-0,59910$ \\
\hline Ireland [1999] & $-0,60975$ & $-0,41524$ \\
\hline Israel [2001] & $-0,49082$ & $-0,09050$ \\
\hline Italy [1999] & $-0,55784$ & $-0,07662$ \\
\hline Japan [2000] & $-0,56309$ & $-0,13872$ \\
\hline Jordan [2001] & 1,25786 & $-0,94243$ \\
\hline Kyrgyzstan [2003] & 0,56410 & 0,69381 \\
\hline Latvia [1999] & $-0,39771$ & 0,59187 \\
\hline Lithuania [1999] & 0,09780 & 1,81607 \\
\hline Luxembourg [1999] & $-1,23280$ & 0,22259 \\
\hline Macedonia, Republic of [2001] & 0,54884 & 0,82797 \\
\hline Malta [1999] & 0,73998 & $-0,34532$ \\
\hline Mexico [2000] & 0,38685 & 0,40264 \\
\hline Morocco [2001] & 1,18597 & $-0,85225$ \\
\hline Netherlands [1999] & $-2,37923$ & $-1,33596$ \\
\hline New Zealand [1998] & $-1,12324$ & $-0,57700$ \\
\hline Nigeria [2000] & 0,96989 & $-0,53043$ \\
\hline Norway [1996] & $-1,40500$ & $-0,67692$ \\
\hline Pakistan [2001] & 1,22330 & $-0,16422$ \\
\hline Peru [2001] & 0,49801 & 0,25632 \\
\hline Philippines [2001] & 1,06083 & 0,74534 \\
\hline Poland [1999] & 0,25855 & 0,49050 \\
\hline Portugal [1999] & $-0,57290$ & 0,50291 \\
\hline Republic of Korea [2001] & 1,06552 & 0,29930 \\
\hline Republic of Moldova [2002] & 0,90879 & 2,44318 \\
\hline Romania [1999] & 0,73986 & 0,73428 \\
\hline Russian Federation [1999] & $-0,25748$ & 1,74323 \\
\hline Saudi Arabia [2003] & 0,94484 & $-0,42943$ \\
\hline Serbia [2001] & $-0,21779$ & 0,51637 \\
\hline Singapore [2002] & 0,39791 & $-0,09253$ \\
\hline Slovakia [1999] & $-0,06542$ & 1,00414 \\
\hline Slovenia [1999] & $-0,66117$ & 0,62790 \\
\hline South Africa [2001] & 0,74342 & 0,21813 \\
\hline Spain [2000] & $-1,01087$ & 0,22768 \\
\hline Sweden [1999] & $-2,12020$ & $-1,37100$ \\
\hline Switzerland [1996] & $-1,31573$ & $-0,41449$ \\
\hline Tanzania, United Republic Of [2001] & 1,28572 & $-2,24675$ \\
\hline Turkey [2001] & 1,46386 & 0,52287 \\
\hline Uganda [2001] & 0,85649 & $-0,42537$ \\
\hline
\end{tabular}




\begin{tabular}{|l|c|c|}
\hline Ukraine [1999] & 0,08443 & 1,75682 \\
\hline United States [1999] & $-0,66609$ & $-1,55408$ \\
\hline Uruguay [1996] & $-0,84206$ & $-0,30694$ \\
\hline Venezuela [2000] & 0,57608 & $-0,18172$ \\
\hline Viet Nam [2001] & 0,45080 & $-2,21551$ \\
\hline Zimbabwe [2001] & 1,21187 & $-0,66514$ \\
\hline
\end{tabular}

Note: our own calculations and compilations, based on the World Values Survey data

Our model based on the residuals from Inglehart/Etzioni path of transformation from traditional to modernity shown in Graph 4 has the following mathematical properties:

Graph 4: Residuals from the Inglehart/Etzioni path of transformation from tradition to modernity

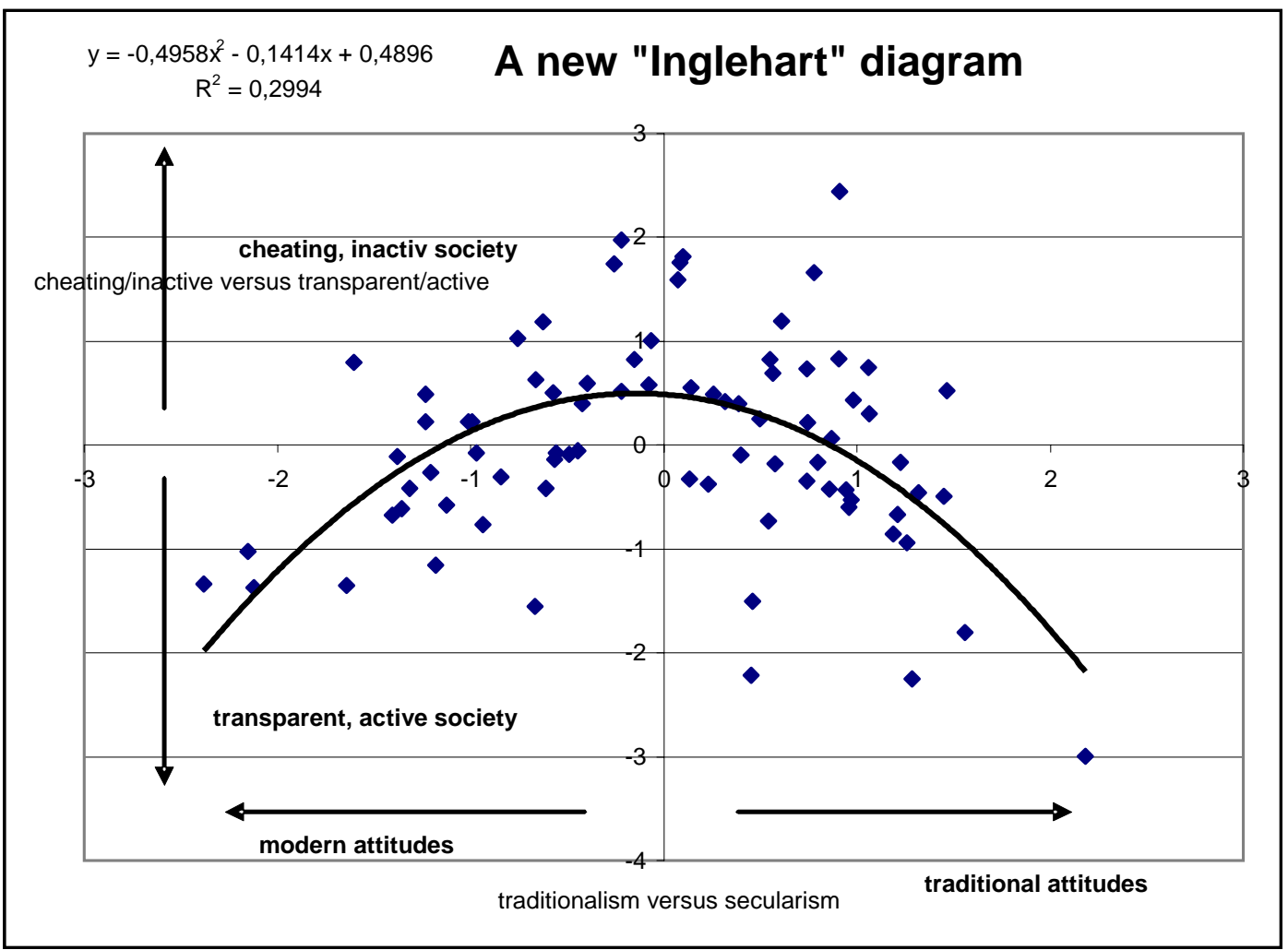

Note: Note: our own calculations and compilations, based on the World Values Survey data, wave $3+4$. The following WVS country values were submitted to an explorative principal component analysis: always respect parents; belief in hell; cheating taxes; education for tolerance and respect important; jobs scarce men have rights; mean acceptability homosexuality; mean acceptance government benefits fraud; never praying; not satisfied with democracy; only God-believing politicians; openly racist; rejecting foreign workers; rejecting homosexual neighbour, belong voluntary welfare elderly; taking bribes; unpaid social welfare work. Our analysis yielded two factors: a continuum of "traditional versus secular”, and a continuum „,cheating versus active society“. Asabiyya is defined then empirically by the residuals from the factor scores of "traditional versus secular", and „cheating versus active society“. Asabiyya means high secularism and a high active society score, thus avoiding the "modernization trap" of an increasingly secular society, which accepts cheating on taxes; accepts government benefits fraud and taking bribes. According to the empirical analysis of this essay, the "active society" of 
volunteer organization work is the best societal medicine against this kind of value decay, which is so common in countries like France, Brazil, or most of East Central Europe and the former USSR

The residuals from the above function now can be called a modern, factor analytical and regression analytical definition of "Asabiyya". It is also interesting to note that Muslim societies approximately adhere to the same process of secularization, but that their chances to recover from the "trough" of the modernization crisis are better than for the global average.

Thus, a modern vision of Islam in the $21^{\text {st }}$ Century would exactly presuppose to provide an answer to the "trough" of the "modernization crisis" around the world - to stimulate an active law-abiding society, and give an answer to the secularization of values by networks of volunteers. The result of our analysis on how Islam could overcome the modernization crisis is depicted in Table 2. The rank of countries by secular, active, trend global and Muslim active society indices are as follows:

Table 2: How Islam could overcome the modernization crisis

\begin{tabular}{|l|c|c|c|c|}
\hline & secular society & active society & $\begin{array}{c}\text { trend global } \\
\text { active society }\end{array}$ & $\begin{array}{c}\text { trend Muslim } \\
\text { active society }\end{array}$ \\
\hline Albania [2002] & $-0,98230$ & $-0,4326$ & 0,12772691 & 0,08530043 \\
\hline Algeria [2002] & $-1,45209$ & 0,49094 & 0,76124692 & 0,85197953 \\
\hline Azerbaijan [1997] & $-0,61006$ & $-1,19167$ & $-0,21882790$ & $-0,23519324$ \\
\hline Bangladesh [2002] & $-2,18350$ & 2,99290 & 2,18320337 & 2,85004324 \\
\hline Bosnia and Herzegovina [2001] & $-0,31595$ & $-0,42056$ & $-0,39546735$ & $-0,30897578$ \\
\hline Egypt [2000] & $-1,55878$ & 1,80361 & 0,93561723 & 1,08240801 \\
\hline Indonesia [2001] & $-1,32012$ & 0,45486 & 0,56117711 & 0,59578959 \\
\hline Iran (Islamic Republic of) [2000] & $-0,54234$ & 0,72874 & $-0,26710175$ & $-0,26621937$ \\
\hline Iraq [2004] & $-0,95986$ & 0,59910 & 0,10294314 & 0,05879277 \\
\hline Jordan [2001] & $-1,25786$ & 0,94243 & 0,47278557 & 0,48599817 \\
\hline Kyrgyzstan [2003] & $-0,56410$ & $-0,69381$ & $-0,25208614$ & $-0,25716565$ \\
\hline Morocco [2001] & $-1,18597$ & 0,85225 & 0,37550415 & 0,36805510 \\
\hline Nigeria [2000] & $-0,96989$ & 0,53043 & 0,11395901 & 0,07052692 \\
\hline Pakistan [2001] & $-1,22330$ & 0,16422 & 0,42537934 & 0,42811761 \\
\hline Saudi Arabia [2003] & $-0,94484$ & 0,42943 & 0,08663335 & 0,04156528 \\
\hline Turkey [2001] & $-1,46386$ & $-0,52287$ & 0,77992942 & 0,87637738 \\
\hline & & & & \\
\hline
\end{tabular}

Note: see note under Table 1

The trend line graphs for different world and Muslim societies in Graph 5 show that Muslim nations have more social cohesion in the process of modernization: 
Graph 5: Muslim nations have more "Asabiyya” (social cohesion) in the process of modernization
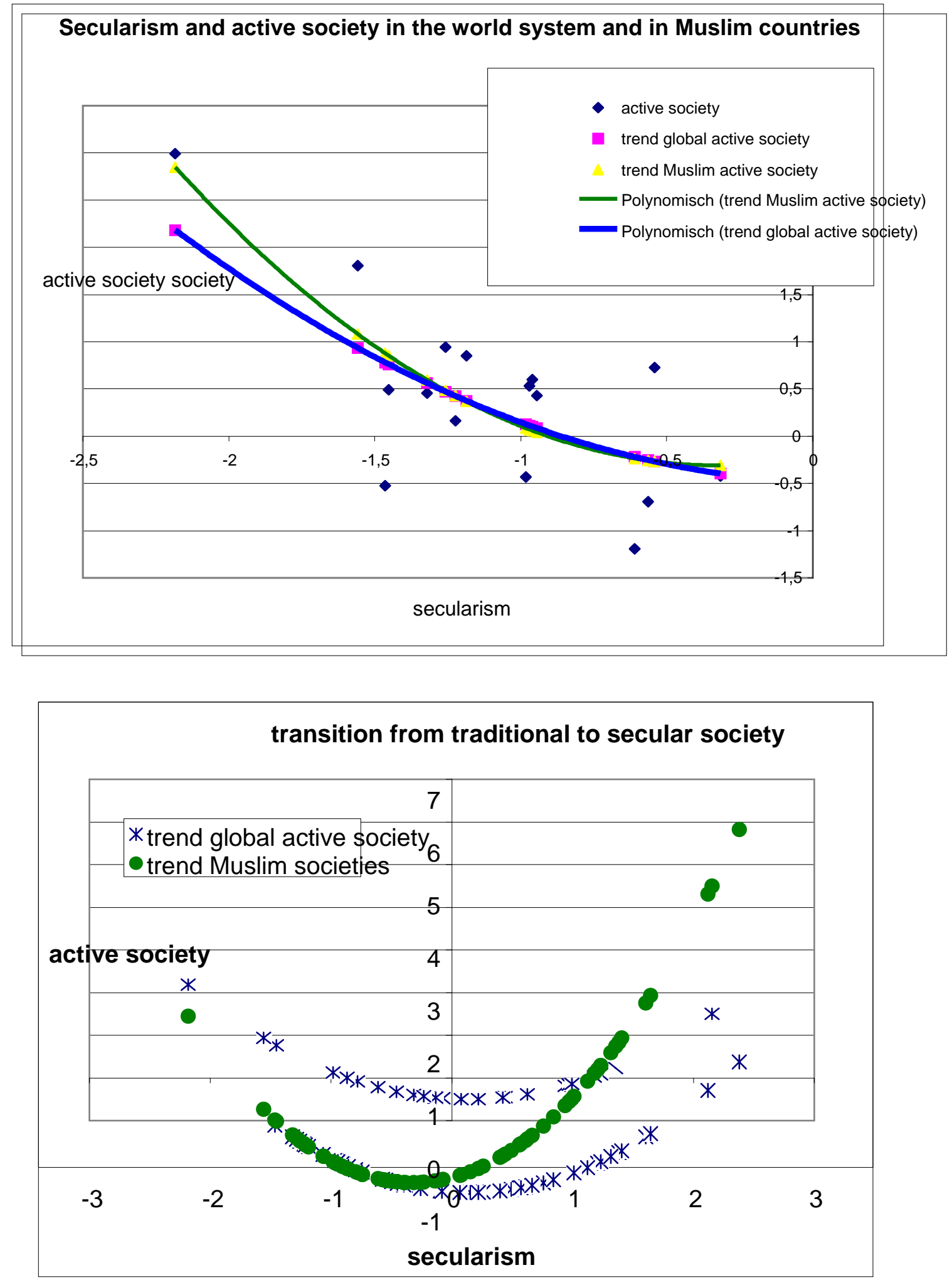

Notes: see before 


\section{The country maps of global value change}

In the following, we will try to map the main results of our analysis on a global scale. We specified that Asabiyya is a high residual along the pathway of modernization; societies which are active and transparent along the course of the secularization process are characterized by Asabiyya.

The global logic of Asabiyya has the following basic characteristics. First we look at the continuum traditional versus secular. The factor "traditional societies versus secular societies” has positive factor loadings above 0.500 with:

- always respect parents

- belief in hell

- jobs scarce men have rights

- rejecting foreign workers

- openly racist

- rejecting homosexual neighbors

- only God-believing politicians

The factor "traditional societies versus secular societies" has negative factor loadings of minus 0.500 or more with the variables:

- mean acceptability homosexuality

- education for tolerance and respect important

- never praying

The map of this traditional universe (see Map1) is characterized as follows: the traditionalist cultural gap in San Diego, California, USA, is far less pronounced as the traditionalist versus secular gap which separates Europe from its Muslim neighbors; and in general, Muslim countries are presenting the most traditional "landscape". The ten most traditional societies in the world are all Muslim societies or are heavily influenced by Muslim culture:

- Bangladesh [2002]

- Tanzania [2001]

- Egypt [2000]

- Turkey [2001]

- Algeria [2002]

- Jordan [2001]

- Indonesia [2001]

- Pakistan [2001]

- Zimbabwe [2001]

- Morocco [2001]

The ten most secular countries on earth are:

- Netherlands [1999]

- Denmark [1999]

- Sweden [1999]

- Iceland [1999]

- France [1999]

- Norway [1996]

- Germany West [1999]

- Finland [2000]

- Switzerland [1996]

- Luxembourg [1999]

As is shown in Map 1, El Salvador, Romania and South Korea are the most traditionalist western countries, while in the Middle East region; Iran already reached an intermediate stage: 
Map 1: Traditional versus secular values in the global system

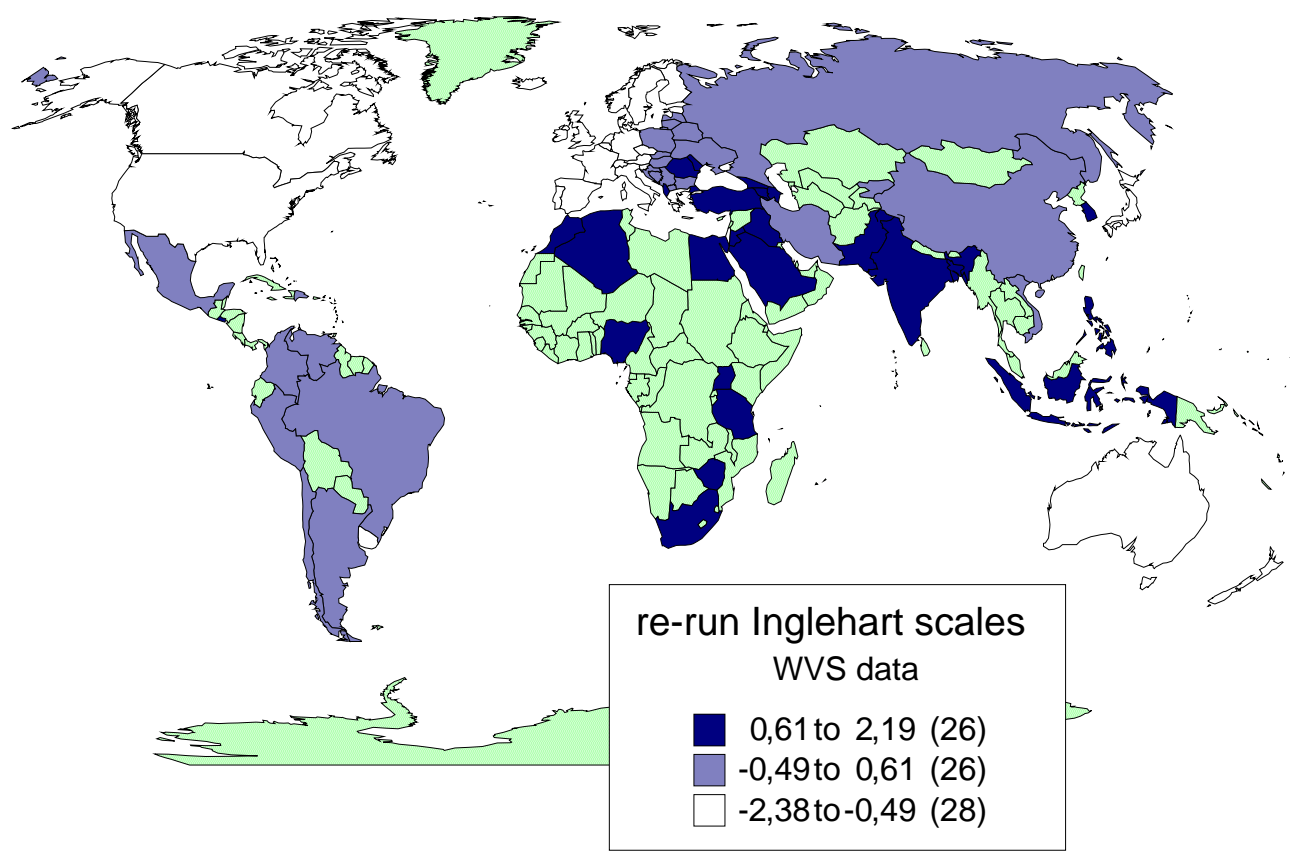

Note: see before. Missing values for Ecuador, Bolivia, and Paraguay, most of Central America, Africa, West Asia and South-east Asia.

The intransparent, inactive society which emerges on Factor 2 of our model is characterized by loadings of more than 0.500 with the following variables:

- cheating taxes

- taking bribes

- not satisfied with democracy

- mean acceptance government benefits fraud

The highest negative loadings (i.e. signs of a transparent, active society) of minus 0.500 or more are achieved on this factor by the variables:

- belong voluntary welfare elderly

- unpaid social welfare work

In a way, Etzioni's "active society” paradigm shows the way how a society can steer the pathways of modernization and secularization. If you want to avoid having a society, where cheating taxes, taking bribes, dissatisfaction with democracy and acceptance of government benefits frauds becomes the rule, you have to mobilize society in volunteer organizations, all the more so in a multicultural society. This is a 
most welcome form of "djihad"; the "djihad" of caring for the elderly and sick, the "djihad" of unpaid social welfare work, the "djihad" of bringing cakes to the home for the elderly, and spending an afternoon with disabled children. The cheating versus active society is shown in Map 2. It is no coincidence that some European societies are among the most crisis-ridden countries along this global scale:

- Republic of Moldova [2002]

- Belarus [2000]

- Lithuania [1999]

- Ukraine [1999]

- Russian Federation [1999]

But also developments in:

- Slovakia [1999]

- Georgia [1996]

- Macedonia, Republic of [2001]

- Hungary [1999]

- France [1999]
- Armenia [1997]

- Brazil [1997]

- Azerbaijan [1997]

- Estonia [1999]

- Greece [1999]

- Philippines [2001]

- Romania [1999]

- Kyrgyzstan [2003]

- Slovenia [1999]

- Latvia [1999]

are far from satisfactory. The real stars along this scale are:

- Bangladesh [2002]

- Tanzania [2001]

- Viet Nam [2001]

- Egypt [2000]

- United States [1999]
- China [2001]

- Sweden [1999]

- Iceland [1999]

- Netherlands [1999]

- Canada [2000]

These are the societies, where civil society is fairly developed and where resistance against the darker sides of modernity - the kind of moral decay, which you associate with cheating taxes, taking bribes, dissatisfaction with democracy, and acceptance of government benefits fraud, is greatest. 
Map 2: The cheating versus the active society - global values in the global system

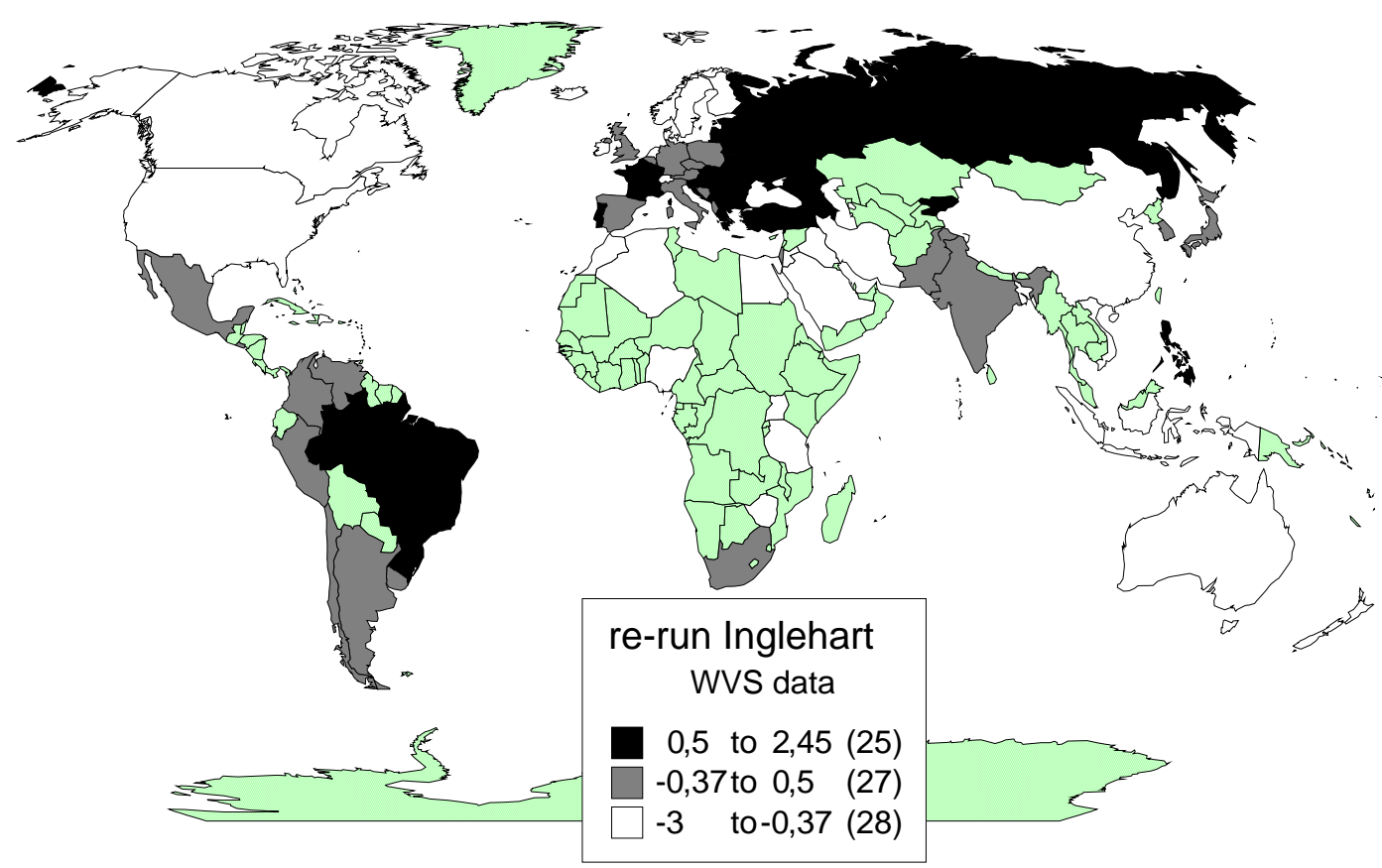

Note: see before. Missing values for Ecuador, Bolivia, and Paraguay, most of Central America, Africa, West Asia and South-east Asia.

"Asabiyya" is nothing else, but the ability of a society to perform well along the path of Graph 5. All upward residuals (good transparency standards, good volunteer services, the process of modernization, i.e. secularization notwithstanding) are societies possessing "Asabiyya", while societies, which are intransparent and do not care for the social needy in voluntary services, do not possess "Asabiyya". The 20 leading countries along this scale are:

- Viet Nam [2001]

- United States [1999]

- China [2001]

- Tanzania, [2001]

- Canada [2000]

- Iran [2000]

- Australia [1995]

- Egypt [2000]

- Bangladesh [2002]

- Ireland [1999]
- Dominican Republic [1996]

- Colombia [1998]

- Iceland [1999]

- New Zealand [1998]

- Uruguay [1996]

- Japan [2000]

- Israel [2001]

- Argentina [1999]

- Iraq [2004]

- Italy [1999] 
The 20 most problematic country cases are:

- Republic of Moldova [2002]

- Armenia [1997]

- Belarus [2000]

- France [1999]

- Lithuania [1999]

- Turkey [2001]

- Ukraine [1999]

- Russian Federation [1999]

- Brazil [1997]

- Azerbaijan [1997]
- Philippines [2001]

- Georgia [1996]

- Estonia [1999]

- Greece [1999]

- Netherlands [1999]

- Romania [1999]

- Belgium [1999]

- Macedonia, Republic of [2001]

- Albania [2002]

- Republic of Korea [2001]

In a way, their social cohesion is severely threatened, and they are very much in need of the positive role models, which are so characteristic of Amitai Etzioni's "active society". It is interesting to note that there are two categories of Muslim societies along this scale - the high "Asabiyya” Muslim countries, like Iran, Egypt, Bangladesh, and the post-communist or post secularism Muslim countries, like Turkey, Azerbaijan and Albania, characterized by low values of "social cohesion".

Based on our result, the world map of Global Asabiyya, shown in Map 3, is the following:

Map 3: Global Asabiyya - countries with a high capacity to avoid the modernization trap of high secularism + loss of civic values, absolutely needed for the functioning of a democracy and the market economy

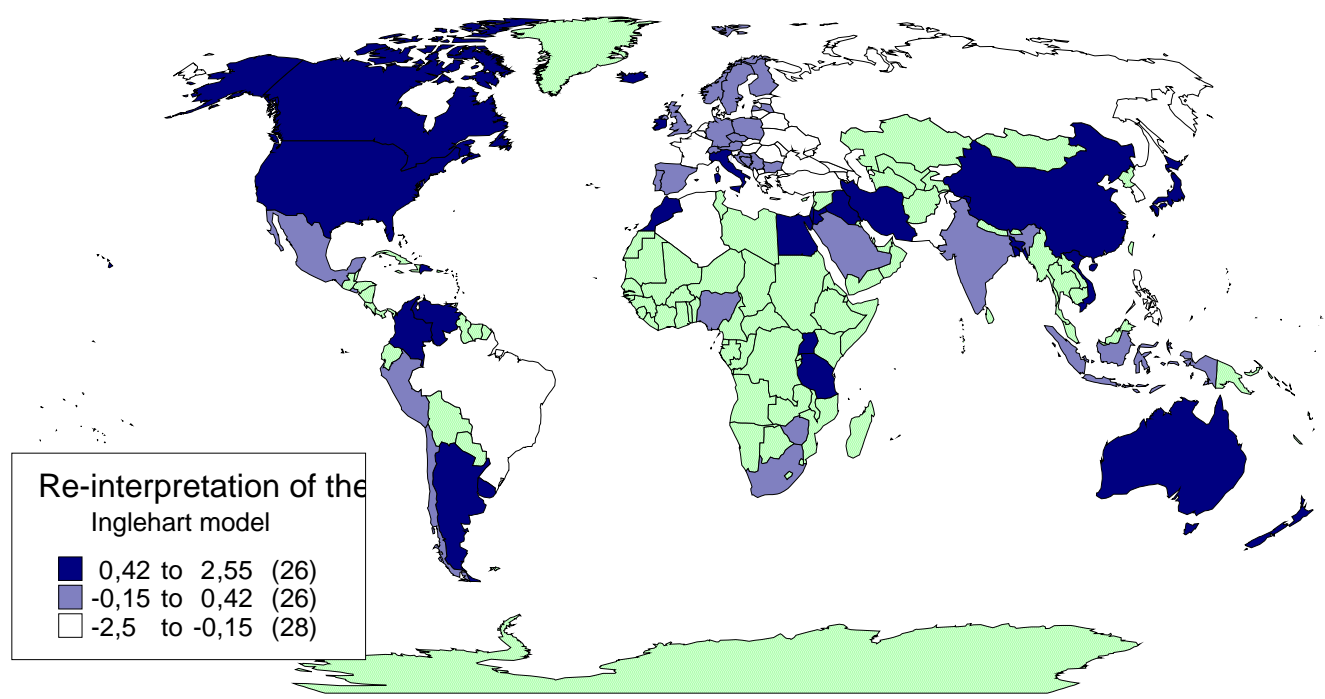

Note: see before. Missing values for Ecuador, Bolivia, and Paraguay, most of Central America, Africa, West Asia and South-east Asia. 


\section{Global Value change and socio-economic development}

In the following, we will analyze the relationships of these social cohesion variables and value indices with current economic growth during the ongoing global recession. We wish to know whether this severe economic crisis have anything to do with the landscapes of social values, analyzed in this article? Our analysis of the relationship between our independent variables and economic growth (based on IMF data and projections, 2009) will be presented in the shortest possible fashion.

The world maps of the estimates of economic growth in 2009 and 2010, based on the IMF (2009) data system seem to confirm the fundamental shifts in world economic centres of gravity, already predicted by Frank, 1998, underlining the necessity to reflect some of the basic assumptions of the development theory discipline. We show the economic growth in 2009 and 2010 in Map 4.A and Map 4.B.

Map 4.A: Economic growth in the world system, 2009

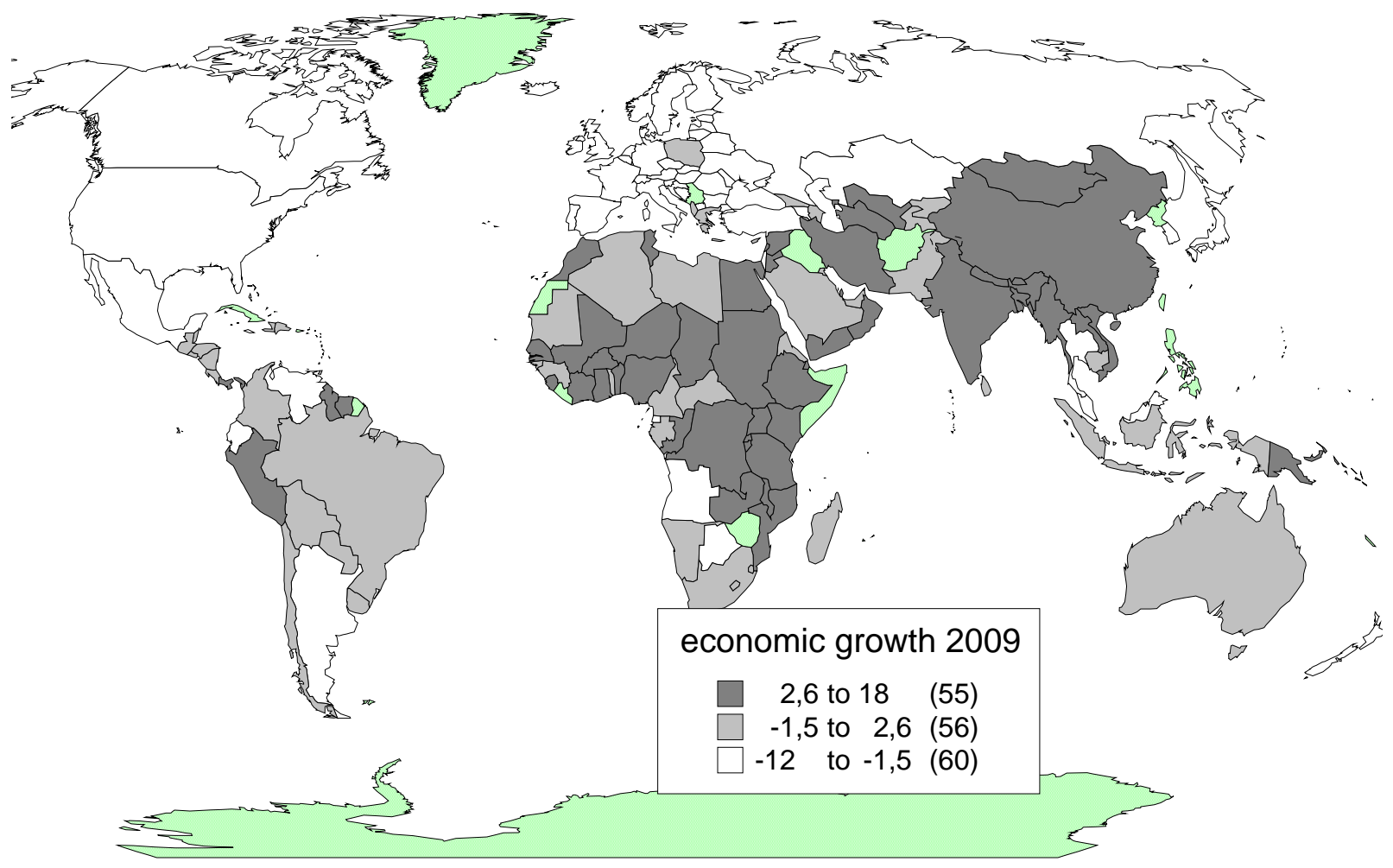

Note: Missing values for Greenland, Serbia, and some countries in Africa and West Asia.

Source: our own map from the data of

http://www.imf.org/external/pubs/ft/weo/2009/01/weodata/weoselgr.aspx 
Map 4.B: Economic growth in the world system, 2010

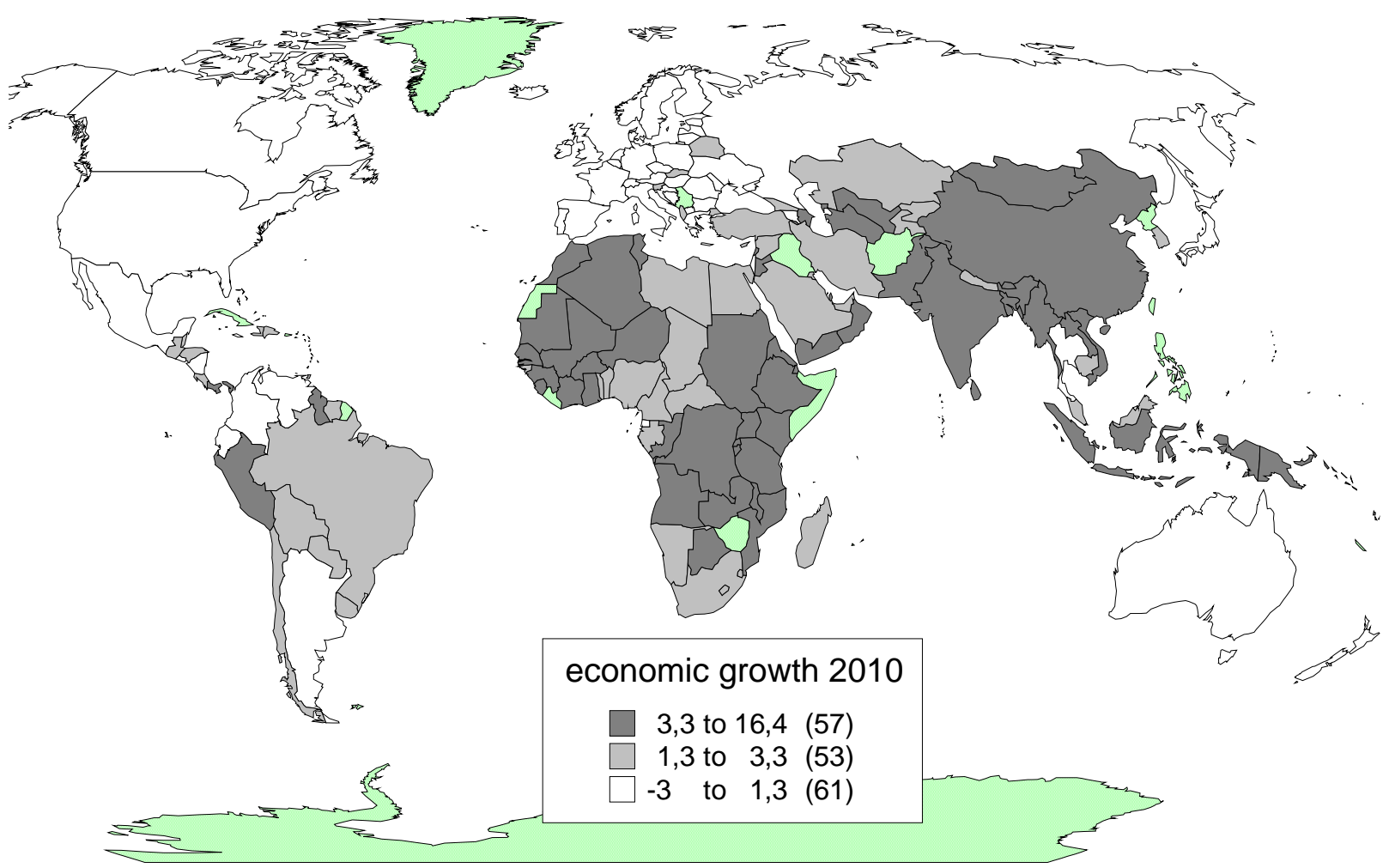

Note: Missing values for Greenland, Serbia, and some countries in Africa and West Asia.

Source: our own map from the data of

http://www.imf.org/external/pubs/ft/weo/2009/01/weodata/weoselgr.aspx

The dependent variable is predicted economic growth in 2009 and 2010. The variations in economic growth among countries are explained by the independent variables of our analysis correspond to the following data:

- Percent of the adult population engaged in voluntary social work (World Values Survey, aggregate country data, wave $3+4$ )

- Percent of the adult population saying they believe in hell (World Values Survey, aggregate country data, wave $3+4$ )

- Asabiyya - see above (principal component analysis, based on World Values Survey data, aggregate country data, wave $3+4$ )

- Cheating society - see above (principal component analysis, based on World Values Survey data, aggregate country data, wave $3+4$ )

- Kearney globalization - see below

- $\quad$ ln GDP per capita (UNDP, 2005)

- $\quad$ ln GDP per capita^2 (UNDP, 2005) 
- Traditional society - see above (principal component analysis, based on World Values Survey data, aggregate country data, wave $3+4$ )

The explanatory power of the variables presented here, is also compared by Kearney's globalization index (See Map 5). The Kearney index has much to do with openness, connectivity, and also infrastructure (see Kearney A. T. 2002; 2003; furthermore Heshmati, 2006). The Kearney Index combines the dimension of foreign direct investment with government transfers; Gross Domestic Product; international organization membership; international travel; internet hosts; internet users; peacekeeping missions; population; remittances and personal transfers; secure Internet servers; telephone traffic; trade; and treaties. Not surprisingly, in 2007 the ten most globalized countries according to the Kearney methodology were Singapore, Hong Kong, the Netherlands, Switzerland, and Ireland, followed by Denmark, the United States, Canada, Jordan and Estonia. The typical peripheries and semi-peripheries of the world system are generally ranked very low on the Kearney index. The rank of the countries differ somewhat, when a parametric approach is used where, unlike in the Kearney index, different weights are attached to different globalization index components (for details see Heshmati, 2006). But we decided to use here the untransformed original indicator for 2004.

Map 5: Kearney’s globalization

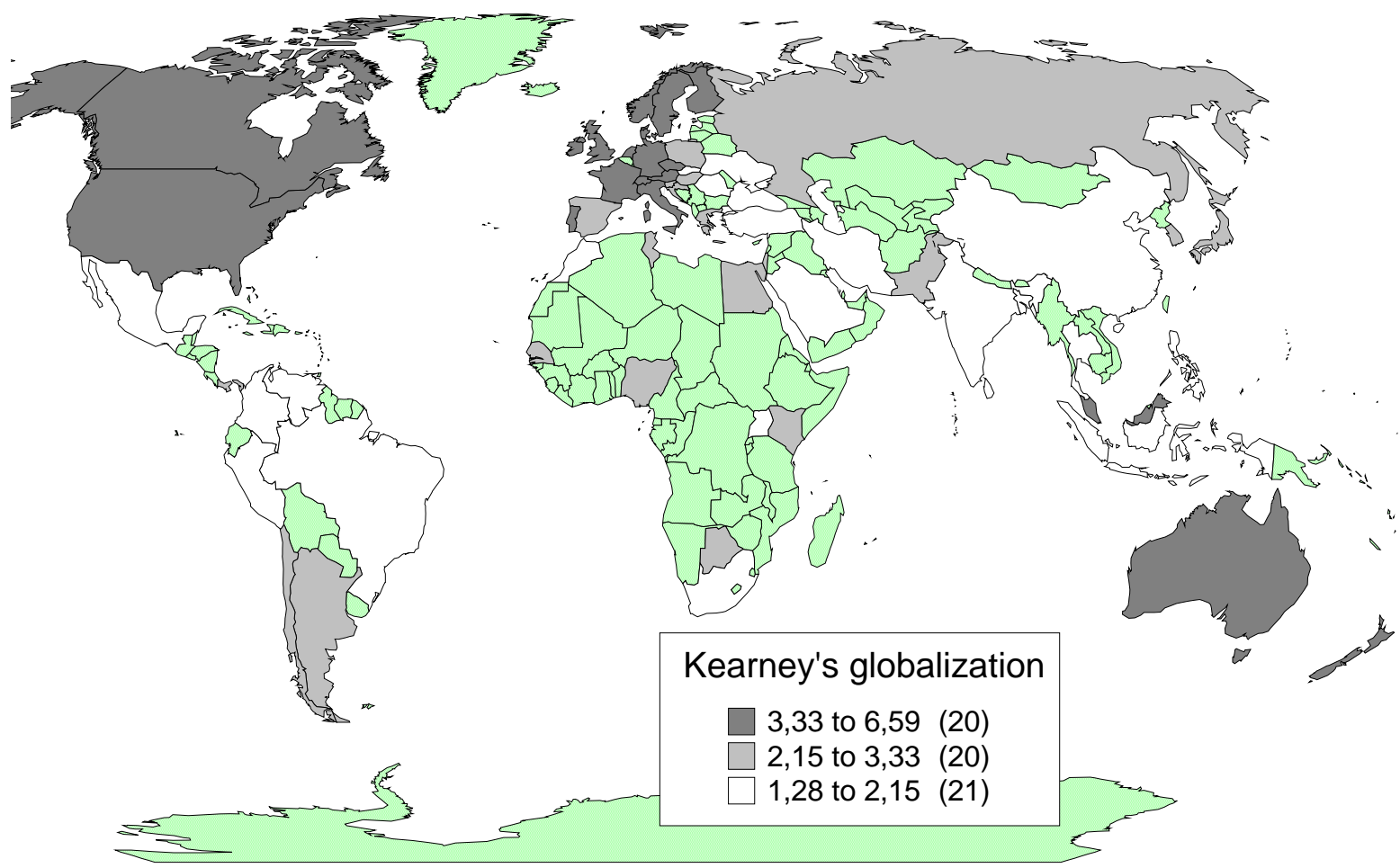

Note: Missing values for Greenland, Iceland, several countries in Central and South America, Africa, and West Asia and Southeast Asia.

Source: our own map from the data presented by Kearney and Bhandari/Heshmati 
Graph 6 and 7 show the bi-variate statistical relationship between Kearney's globalization index and economic growth in 2009 and 2010. The first order coefficient in both cases is negative while the squared coefficient is positive and statistically significantly different from zero. Globalization explains 24 and 27 percent of the variations in predicted economic growth in 2009 and 12010, respectively. The data suggest that there is an inverse and quite remarkable relationship between past globalization and growth perspectives in 2009 and 2010, suggesting that economic growth in the world system now shifts towards those countries that rank lower on Kearney's globalization index, while the highly globalized country bear the full brunt of the economic depression. The economic crisis threw the highly globalized countries into the abyss of depression, while the less globalized countries are the shining new superstars. This is evidenced by fast recovery of the Korean, Chinese and Indian economies and their ability to experience positive economic growth while all highly globalized economies still suffer from the effects of financial crisis.

Graph 6: Globalization (Kearney) and economic growth, 2009

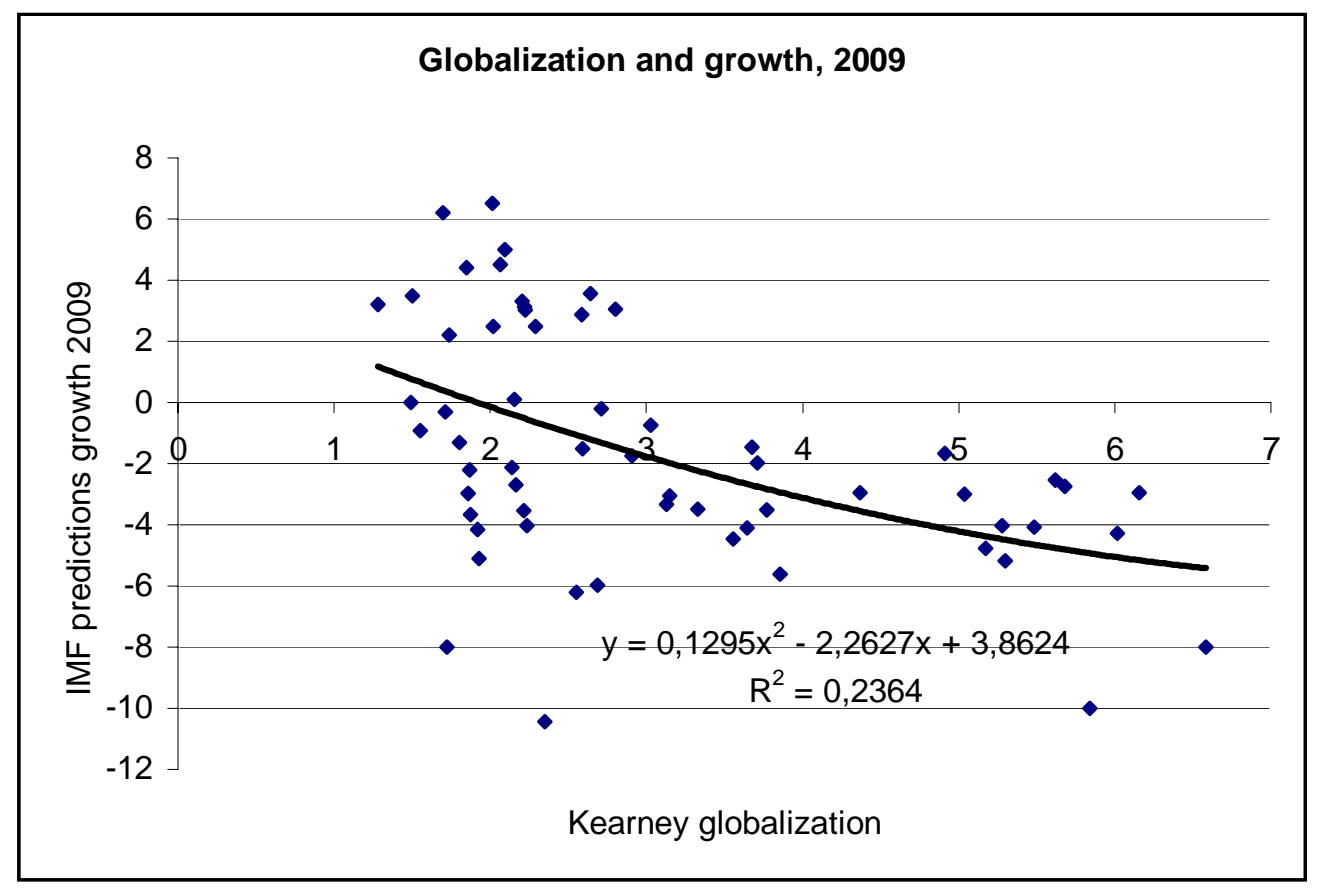

Source: our own Microsoft EXCEL 2003 graph, based on the data by IMF 2009 (observed and projected economic growth, 2009) and Kearney’s globalization index (Bhandari/Heshmati, 2008). 
Graph 7: Globalization (Kearney) and economic growth, 2010

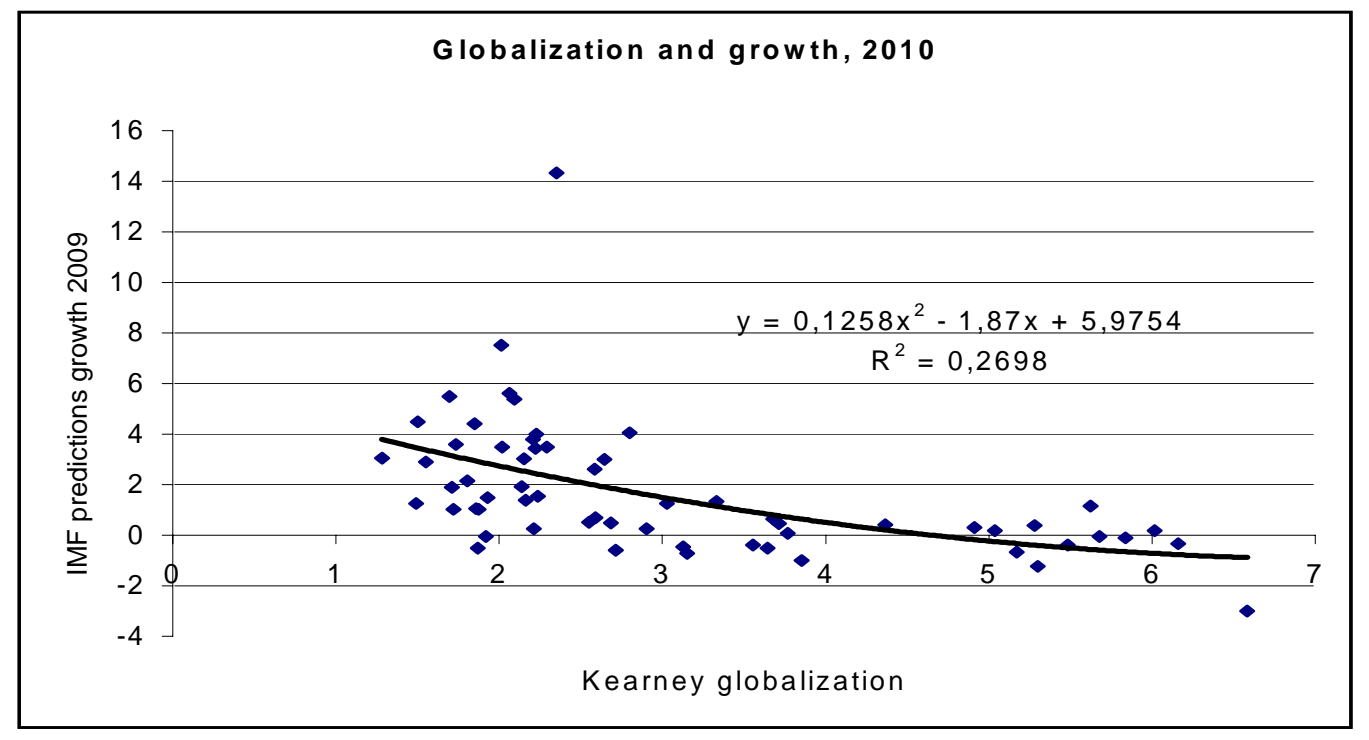

Source: our own Microsoft EXCEL 2003 graph, based on the data by IMF 2009 (predicted economic growth, 2010) and Kearney’s globalization index (Bhandari/Heshmati, 2008).

Table 3 now compares the predictive power of Barro's master variable - belief in hell with one of the most important background variables of this article, voluntary social work, which can be well-founded in the active society paradigm by Etzioni, 1968. For reasons of brevity, we only compare the predictive power for the 2010 projections, and omit here the results for 2009, because the data for 2010 are certainly more futureoriented. According to standard macro-quantitative development research praxis, we include the natural logarithm of per capita income and its square as an additional controlling variable. The result for 2010 in Table 3 show that belief in hell and log of GDP per capita and its square doe not have effect on the predicted level of economic growth but voluntary social work does positively. These variables dominated by voluntary work explain 58 percent of the variations in predicted economic growth in 2010.

Table 3: Volunteers and belief in hell in the explanation of economic growth, 2010 (IMF prediction)

\begin{tabular}{|l|c|c|c|c|c|c|}
\hline & & B & $\begin{array}{c}\text { Standard } \\
\text { error }\end{array}$ & Beta & T & $\begin{array}{c}\text { Error } \\
\text { probability }\end{array}$ \\
\hline & (Constant) & 4,455 & 14,957 & & 0,298 & 0,767 \\
\hline Belief in hell & VAR00008 & 0,009 & 0,009 & 0,114 & 1,043 & 0,303 \\
\hline Voluntary social work & VAR00020 & 0,113 & 0,039 & 0,333 & 2,887 & 0,006 \\
\hline ln GDP per capita & VAR00070 & 0,162 & 3,273 & 0,08 & 0,049 & 0,961 \\
\hline ln GDP per capita^2 & VAR00071 & $-0,070$ & 0,18 & $-0,616$ & $-0,388$ & 0,700 \\
\hline
\end{tabular}

$\mathrm{N}=51 ;$ adj. $\mathrm{R} \wedge 2=57.8 \% ; \mathrm{F}=18.089 ; \mathrm{p}=.000$.

Source: our own calculations, based on the data of this article and SPSS XIV - XV; as implemented at the Computing Centre, Innsbruck University, Austria 
The result for 2009 in Table 4 show that belief in hell and again log of GDP per capita and its square doe not have any effect on the predicted level of economic growth. Traditional and cheating society and level of globalization affect negatively the predicted level of economic growth, while Asabiyya influences economic growth positively. These variables together explain 69 percent of the variations in predicted economic growth in 2009. In 2010 only cheating remains statistically significant contributor to a negative economic growth. The fit of the model is lower, but yet $64 \%$ of the variations in predicted economic growth in 2010 are explained by the model.

Table 4: Predicting economic growth, 2009

\begin{tabular}{|l|c|c|c|c|c|c|}
\hline & & B & $\begin{array}{c}\text { Standard } \\
\text { error }\end{array}$ & Beta & T & $\begin{array}{c}\text { Error } \\
\text { probability }\end{array}$ \\
\hline & (Constant) & 30,108 & 37,087 & & 0,812 & 0,421 \\
\hline ln GDP per capita & VAR00070 & $-3,519$ & 8,432 & $-0,878$ & $-0,417$ & 0,678 \\
\hline ln GDP per capita^2 & VAR00071 & 0,048 & 0,483 & 0,219 & 0,100 & 0,921 \\
\hline Traditional society & VAR00001 & $-1,246$ & 0,528 & $-0,352$ & $-2,361$ & 0,023 \\
\hline Cheating society & VAR00002 & $-1,249$ & 0,541 & $-0,303$ & $-2,308$ & 0,026 \\
\hline Asabiyya & VAR00003 & 1,267 & 0,618 & 0,243 & 2,049 & 0,046 \\
\hline Kearney globalization & VAR00064 & $-1,085$ & 0,417 & $-0,444$ & $-2,604$ & 0,012 \\
\hline
\end{tabular}

$\mathrm{N}=52 ;$ adj. $\mathrm{R} \wedge 2=68.6 \% ; \mathrm{F}=19.575 ; \mathrm{p}=.000$

Source: our own calculations, based on the data of this article and SPSS XIV - XV; as implemented at the Computing Centre, Innsbruck University, Austria

Table 5: Predicting IMF economic growth, 2010

\begin{tabular}{|l|c|c|c|c|c|c|}
\hline & & B & $\begin{array}{c}\text { Standard } \\
\text { error }\end{array}$ & Beta & T & $\begin{array}{c}\text { Error } \\
\text { probability }\end{array}$ \\
\hline & (Constant) & $-1,554$ & 21,824 & & $-0,071$ & 0,944 \\
\hline ln GDP per capita & VAR00070 & 2,313 & 4,962 & 1,046 & 0,466 & 0,643 \\
\hline ln GDP per capita $\wedge 2$ & VAR00071 & $-0,198$ & 0,284 & $-1,628$ & $-0,695$ & 0,490 \\
\hline Traditional society & VAR00001 & $-0,145$ & 0,311 & $-0,074$ & $-0,468$ & 0,642 \\
\hline Cheating society & VAR00002 & $-0,695$ & 0,318 & $-0,306$ & $-2,184$ & 0,034 \\
\hline Asabiyya & VAR00003 & 0,225 & 0,364 & 0,078 & 0,618 & 0,540 \\
\hline Kearney globalization & VAR00064 & $-0,420$ & 0,245 & $-0,312$ & $-1,714$ & 0,093 \\
\hline
\end{tabular}

$\mathrm{N}=52 ;$ adj. $\mathrm{R} \wedge 2=64.3 \% ; \mathrm{F}=16.310 ; \mathrm{p}=.000$

Source: our own calculations, based on the data of this article and SPSS XIV - XV; as implemented at the Computing Centre, Innsbruck University, Austria

Our equations show the predictive power of the new value change paradigm for explaining future economic growth. No growth is possible without an active and honest society. It would be interesting to examine the relationship by using panel data to evaluate the long term effect of such association accounting for country heterogeneity by level of development and form of societies. 


\section{Conclusion}

We have shown in this article that quantitative evidence suggests that the transition of a traditional towards a modern society presupposes the existence of at least functioning networks of volunteer organizations, often motivated by religious or post-religious humanism and altruism. To negate this dimension of the necessary "Asabiyya" of a society would certainly open up the way of social decay, so aptly described by the Arab historian and philosopher Ibn Khaldoun centuries ago. Phenomena of child poverty in developed countries, extensively documented in Heshmati/Tausch/Bajalan, 2008, are just one sign of this social decay, which goes along with the hyper-destruction of classic family structures in the process of what is called "modernization". Strict separation of state and religious communities and demand for full gender equality, yes, but a society needs the compassion and the humanism and the volunteer work of both non-religious and religious humanists in order to survive. This is also an important roadmap for the question of the role of religion in a modern society. 


\section{General Sources and Bibliography}

Abdullah M. S. and Khoury A. Th. (1984), 'Mohammed für Christen. Eine Herausforderung' Freiburg, Basel, Wien: Herder.

Amin S. (1989), 'Eurocentrism’ Translated by Russell Moore. New York: Monthly Review Press.

Andersen T.M. and T.T. Herbertsson (2003), Measuring Globalization. IZA Discussion Paper. 2003:817. Bonn: IZA.

Arcelus F., B. Sharma and G. Srinivasan (2005), 'Assessing the information content of the technology achievement index in the presence of the human development index' Economics Bulletin 15(4), 1-5.

Archibugi D. and A. Coco (2004), A New Indicator of Technological Capabilities for Developed and Developing Countries (ArCo), World Development 32(4), 629-654.

Armstrong K. (1992), 'Muhammad: a biography of the prophet' San Francisco, Calif.: Harper SanFrancisco.

Armstrong K. (1993), 'A history of God: the 4000-year quest of Judaism, Christianity, and Islam.' New York : A.A. Knopf: Distributed by Random House.

Armstrong K. (2000), 'Islam: a short history'. New York: Modern Library.

Armstrong K. (2006), 'Muhammad: a prophet for our time' New York: Atlas Books/HarperCollins.

Aydin H. et al. (2003), “”Euro-Islam”. Das neue Islamverständnis der Muslime in der Migration”. Stiftung Zentrum für Türkeistudien, Institut an der Universität Duisburg-Essen. Available at: http://www.rennerinstitut.at/download/texte/euroisla.pdf .

Balic S. (2001), ,Islam für Europa: neue Perspektiven einer alten Religion’ Köln and Vienna: Böhlau.

Bardakoglu A. (2006), 'Religion and Society. New Perspectives from Turkey.' Ankara: P.P.R.A.

Barro R. J. (2004), 'Spirit of Capitalism Religion and Economic Development'. Harvard International Review, vol. 25, no. 4, pp. 64-67.

Barro R. J. and McCleary R. M. (2004), 'Religion and economic growth' The Milken Institute review (Milken, Santa Monica, Cal.), 6 (2004), 2, S. 36-45.

Barro R.J. and J-W. Lee (2000), International data on educational attainment: updates and implications, Centre for International Development at Harvard University, CID Working Paper 2000:42.

Berger P. L. (2001), ,Holy war, Inc.: inside the secret world of Osama bin Laden' New York: Free Press.

Bhandari A. K. and A. Heshmati (2007), Measurement of Globalization and its Variations among Countries, Regions and over Time, in A. Heshmati and A. Tausch, Roadmap to Bangalore? Globalization, the EU's Lisbon Process and the Structures of Global Inequality, Nova Science Publishers.

BM.I.SIAK (2006), 'Perspektiven und Herausforderungen in der Integration muslimischer MitbürgerInnen in Österreich’ Federal Ministry of the Interior, Republic of Austria, available at: http://www.bmi.gv.at/downloadarea/asyl_fremdenwesen/Perspektiven_Herausf orderungen.pdf . 
Boff L. (2005), 'Global civilization: challenges to society and to Christianity.' London; Oakville: Equinox Publishing.

Bsteh A. (1996), 'Peace for humanity: principles, problems, and perspectives of the future as seen by Muslims and Christians' New Delhi: Vikas Pub. House.

Bsteh A. and Anawati G. C. (1978), ,Der Gott des Christentums und des Islams' Mödling: Verl. St. Gabriel.

Bsteh A. and Dupré W. (2007), ,Christian faith in dialogue with Islam. Lectures, questions, interventions. Mödling St. Gabriel Publ.

Bsteh A. and Khoury A. Th. (1994), 'Der Islam als Anfrage an christliche Theologie und Philosophie' Mödling : Verlag St. Gabriel.

Devezas T. C. (Ed.) (2006), 'Kondratieff waves, warfare and world security: [proceedings of the NATO Advanced Research Workshop on The Influence of Chance Events and Socioeconomic Long Waves in the New Arena of Asymmetric Warfare, Covilhã, Portugal, 14 - 18 February 2005]'. Amsterdam: IOS Press.

Devezas T. C. and Corredine, J.T. (2001), 'The biological determinants of longwave behavior in socioeconomic growth and development'. Technological Forecasting and Social Change, 68, (1), 1-57.

Diez-Nicolás J. (2007), "Value Systems of Elites and Publics in the Mediterranean: Convergence and Divergence" in "Values and Perceptions of the Islamic and Middle Eastern Publics” (Moaddel M. (Ed.)), pp. 47 - 70, Houndmills, Basingstoke, Hampshire: Palgrave Macmillan.

Dittrich M. (2006), 'Muslims in Europe: addressing the challenges of radicalisation'. European Policy Centre in strategic partnership with the King Baudouin Foundation and the Comagnia di San Paolo, Brussels, available at http://www.theepc.be/TEWN/pdf/602431467_EPC\%20Working\%20Paper\%20 23\%20Muslims\%20in\%20Europe.pdf .

Donno D. and Russett B. (2004), 'Islam, Authoritarianism, and Female Empowerment: What Are the Linkages?’ World Politics, vol. 56, no. 4, pp. 582-607.

Erdenir B. (2006), 'The Future of Europe: Islamophobia?' Secretariat General for EU Affairs (EUSG) of Turkey, available at: http://www.turkishpolicy.com/default.asp?show=fall_2005_erdenir (Turkish Policy Quarterly, 2006).

Etzioni A. (1968), "The active society: a theory of societal and political processes.” London, Collier-Macmillan; New York, Free Press.

Etzioni A. (1996), “The new golden rule: community and morality in a democratic society” New York: Basic Books.

Hair J.F., B. Black, B. Babib, A.R. Anderson and R.L. Tatham (2006), 'Multivariate Analysis'. New York: Prentice Hall.

Heshmati A. (2006), 'Measurement of a Multidimensional Index of Globalization'. Global Economy Journal, 6 (2), Paper 1.

Heshmati A. and J-E. Oh (2006), Alternative Composite Lisbon Development Strategy Indices: A Comparison of EU, USA, Japan and Korea, The European Journal of Comparative Economics 3(2), 133-170.

Heshmati A., Tausch A. and Ch. Balajan (2008), ,Measurement and Analysis of Child Well-Being in Middle and High Income Countries.' EJCE, European 
Journal of Comparative Economics, Vol. 5, Issue 2, pp. 187-249, December 2008 , 5(2), 187 - 249.

Hotelling H. (1933), 'Analysis of a Complex of Statistical Variables into Principal Components’ Journal of Educational Psychology 24, 417-441 and 24, 498-520.

HUDSON Institute (Vidino L.) (2006), 'Aims and Methods of Europe's Muslim Brotherhood. Current Trends in Islamist Ideology vol. 4, available at: http://www.futureofmuslimworld.com/research/pubID.55/pub_detail.asp.

Huntington S. P. (1968). 'Political order in changing societies'. New Haven: Yale University Press.

Huntington S. P. (1996), 'The clash of civilizations and the remaking of world order' New York: Simon \& Schuster.

Ibn Khaldun (1332-1406) (2005), 'The Muqaddimah: an introduction to history. Ibn Khaldun; translated and introduced by Franz Rosenthal; abridged and edited by N.J. Dawood, with with a new introduction by Bruce B. Lawrence'. Princeton, N.J.: Princeton University Press.

Inglehart R. T. (1990), 'Culture shift in advanced industrial societies' Princeton, N.J.: Princeton University Press.

Inglehart R. T. (2007), "The Worldviews of Islamic Publics in Global Perspective" in "Values and Perceptions of the Islamic and Middle Eastern Publics" (Moaddel M. (Ed.)), pp. 25 - 46, Houndmills, Basingstoke, Hampshire: Palgrave Macmillan.

Inglehart R. T. and Norris P. (2003), 'Rising tide: gender equality and cultural change around the world'. Cambridge, UK ; New York: Cambridge University Press, 2003.

Inglehart R. and Welzel, 2003 R. C. (2003), 'Political Culture and Democracy: Analyzing Cross-Level Linkages.' Comparative Politics, 36, 1: 61-80.

Jabber P. (2001), 'Impact of the War on Terror on Certain Aspects of US Policy in the Middle East. A Medium-Term Assessment' Prepared for the United States National Intelligence Council. Available at: http://www.fas.org/irp/nic/jabber_paper.htm.

Kang S.M. (2002), 'A Sensitivity Analysis of the Korean Composite Environmental Index'. Ecological Economics 43, 159-174.

Katz S. (2006), 'Indicators for complex innovation systems', Research Policy 35(7), 893-909.

Kearney A. T., Inc., and the Carnegie Endowment for International Peace (2002), Globalizations Last Hurrah?’ Foreign Policy, January/February: 38-51.

Kearney, A. T., Inc., and the Carnegie Endowment for International Peace (2003), 'Measuring Globalization: Whos up, whos down?' Foreign Policy, January/February: 60-72.

Khoury A. Th. (1980), ,Toleranz im Islam’ München: Kaiser und Grünwald.

Khoury A. Th. (1991), 'Was ist los in der islamischen Welt? Die Konflikte verstehen' Freiburg, Basel, Vienna: Herder.

Khoury A. Th. (1994), ,Christen unterm Halbmond: religiöse Minderheiten unter der Herrschaft des Islam' Freiburg [im Breisgau]: Herder.

Khoury A. Th. (2001), ,Der Islam und die westliche Welt: religiöse und politische Grundfragen’ Darmstadt: Primus, 2001.

Khoury A. Th. (2002), ,Mit Muslimen in Frieden leben: Friedenspotentiale des Islam’ Würzburg: Echter, 2002. 
Khoury A. Th. (2005), ,Der Koran erschlossen und kommentiert' Patmos.

Khoury A. Th. (2007), ,Der Koran’ Guetersloh: Guetersloher Verlagshaus.

Khoury A. Th. (2007), ,Lexikon religiöser Grundbegriffe, Judentum - Christentum Islam'. Wiesbaden: Marix Verlag.

Khoury A. Th. (2008), 'Der Hadith. Quelle der islamischen Tradition'. Guetersloher Verlagshaus.

Khoury A. Th. (2008), ,Muhammad, Der Prophet und seine Botschaft'. Freiburg: Herder Verlag .

Khoury A. Th. et al. (2006), ,Islam-Lexikon A-Z' Freiburg: Herder.

Lewis B. (1993), ,Islam and the West' New York: Oxford University Press.

Lewis B. (2002), 'What went wrong?: Western impact and Middle Eastern response' Oxford; New York: Oxford University Press, 2002.

Lewis B. (2003), 'The crisis of Islam: holy war and unholy terror' New York: Modern Library.

Lockwood B. (2004), 'How Robust is the Foreign Policy-Kearney Globalization Index?’ The World Economy 27, 507-523.

Mann Th. (1924), 'Buddenbrooks, translated from the German of Thomas Mann, by H.T. Lowe-Porter'. New York: A.A. Knopf.

Mirchandani D. (1999), 'Economic and social indicators of global competitiveness: an analysis of country rankings', 8th International Eastern Academy of Management Conference, (CD Rom version). Prague.

Moaddel M. (2004), 'The future of Islam after 9/11' Futures, 2004, vol. 36, no. 9, pp. 961-977.

Muenz R. (2006), "Population Change and the Impact of Demographic Aging: Consequences and Policy Options for Europe" International Conference on Cultural and Political Conditions for the Reform and Modernisation of Social Models in Europe and the U.S., Vienna, May 19-20, 2006, Institute for Human Sciences, Vienna.

Noland M. (2004), 'Religion and economic performance'. Washington D.C.: The Peterson Institute, available at: http://www.petersoninstitute.org/publications/wp/03-8.pdf .

Noland M. (2005), 'Explaining Middle Eastern Authoritarianism'. Washington D.C., Institute for International Economics, Working Paper Series 05-5 (entire), available at: http://www.iie.com/publications/wp/wp05-5.pdf .

Noland M. and Pack H. (2004), 'Islam, Globalization, and Economic Performance in the Middle East'. International Economics Policy Briefs, Washington D.C., Institute for International Economics, PB 04-4, June (entire), available at: http://www.iie.com/publications/pb/pb04-4.pdf .

Noorbakhsh F. (1998), 'The Human Development Index: Some Technical Issues and Alternative Indices' Journal of International Development, 10, 589-605.

Norris P. and Inglehart R. (2004), 'Sacred and secular: religion and politics worldwide’. Cambridge; Melbourne: Cambridge University Press.

Pearson K. (1901), 'On Lines and Planes of Closest fit to Systems of Points in Space’. Philosophical Magazine 6(2), 559-72.

Pettersson Th. (2007), "Muslim Immigrants in Western Europe: Persisting Value Differences or Value Adaption" in "Values and Perceptions of the Islamic and Middle Eastern Publics” (Moaddel M. (Ed.)), pp. 71 - 104, Houndmills, Basingstoke, Hampshire: Palgrave Macmillan. 
PEW Research Center for the People and the Press (2006), "The Great Divide: How Westerners and Muslims View Each Other. Europe's Muslims More Moderate” PEW, Washington D.C.: http://pewglobal.org/reports/display.php?ReportID=253 (June 22, 2006).

Pipes D. (2002), 'God and Mammon: Does Poverty Cause Militant Islam? The National Interest, Winter 2002, available at: http://www.danielpipes.org/article/104 .

Polanyi K., Lewis J. Kitchin D. (1972), 'Christianity and the social revolution' Freeport, N.Y.: Books for Libraries Press..

RAND Corporation (Ch. Benard) (2005): „Civil Democratic Islam. Partners, Resources, and Strategies“, freely available on the Internet at „Free downloadable PDF file(s) are available below. Full Document (File size 0.7 MB, 3 minutes modem, < 1 minute broadband)“ at http://www.rand.org/pubs/monograph_reports/MR1716/.

RAND Corporation (Rabasa A. M. et al.) (2006), "The Muslim World after 9/11. Prepared for the United States Air Force”. Rand Corporation, Santa Monica, California, Rand Project Air Force, available at: http://www.rand.org/pubs/research briefs/2005/RAND RB151.pdf .

Ravallion M. (2005), 'On measuring aggregate "social efficiency"'. Economic Development and Cultural Change, 53(2), 273-92.

Rennstich J. (2007), 'Is Globalization self-organizing?' In: G. Modelski, T. C. Devezas, W. R. Thompson (Eds.)). Globalization as Evolutionary Process. Modeling Global Change, 74 - 107. London and New York: Routledge.

Saisana M. and S. Tarantola (2002), 'State-of-the-art report on current methodologies and practices for composite indicator development' Joint Research Centre - European Commission, I-21020 Ispra (VA), Italy.

Savage T. M. (2004), 'Europe and Islam: Crescent Waxing, Cultures Clashing’ The Washington Quarterly, Summer, 27, 3: 25-50, available at: http://www.twq.com/04summer/docs/04summer_savage.pdfsearch=\%22cresce nt\%20waxing\%20savage\%22.

Schumpeter J. A. (1950), 'Capitalism, Socialism and Democracy'. New York \& London: Harper \& Row.

Sen A. (1987), Equality for What?, in S.M. McMurrim (ed.), 'Tanner Lectures on Human Values', Vol. 1. Salt Lake City: University of Utah Press.

Sen A. (1992), 'Inequality Re-examined'. Oxford: Clarendon.

Sen A. (1999), 'Development as Freedom'. Oxford: Oxford University Press.

Sen, A. (1985), 'Commodities and Capabilities'. Amsterdam: Elsevier.

SPSS (2007), 'Statistical Package for the Social Sciences, User Guide'. Version 14, August 2007.

Sturgis, P. (2004), 'Analysing Complex Survey Data: Dimensioning, Stratification and Weights' Social Research Update, Issue 43. Downloaded at http://www.soc.surrey.ac.uk/sru/ SRU43.html, January 2006.

Tibi B. (1973), ,Militär und Sozialismus in der Dritten Welt: allgemeine Theorien und Regionalstudien über arabische Länder'. Frankfurt am Main: Suhrkamp.

Tibi B. (1981), 'Arab nationalism: a critical enquiry. Edited and translated by Marion Farouk-Sluglett and Peter Sluglett' London: MacMillan Press, 1981..

Tibi B. (1985), 'Der Islam und das Problem der kulturellen Bewältigung sozialen Wandels’ Frankfurt am Main: Suhrkamp, 1991. 
Tibi B. (1990), ‘Arab nationalism: a critical enquiry’ New York, N.Y.: St. Martin's Press.

Tibi B. (1992), ,Die fundamentalistische Herausforderung: der Islam und die Weltpolitik’ München : C.H. Beck.

Tibi B. (1992), 'Kreuzzug oder Dialog? Der Westen und die arabo - islamische Welt nach dem Golfkrieg' in 'Kreuzzug oder Dialog. Die Zukunft der Nord - Sued Beziehungen' (Matthies V. (Ed.)), pp. 107 - 120, Bonn: J.H.W. Dietz Nachfolger.

Tibi B. (1995), ,Krieg der Zivilisationen: Politik und Religion zwischen Vernunft und Fundamentalismus.' Hamburg: Hoffmann und Campe.

Tibi B. (1996), ,Der Wahre Imam: der Islam von Mohammed bis zur Gegenwart' München: Piper, 1996.

Tibi B. (1997), 'Arab nationalism: between Islam and the nation-state' New York: St. Martin's Press.

Tibi B. (1997), 'Challenge of fundamentalism: political Islam and the new world disorder'. Berkeley: University of California Press.

Tibi B. (1997), 'Conflict and war in the Middle East, 1967-91: regional dynamic and the superpowers. Translated by Clare Krojzl'. Houndmills, Basingstoke, Hampshire: Macmillan in association with the Center for International Affairs, Harvard University.

Tibi B. (1998), 'Conflict and war in the Middle East: from interstate war to new security' New York: St. Martin's Press.

Tibi B. (1998), 'Crisis of modern Islam: a preindustrial culture in the scientifictechnological age. Translated by Judith von Sivers; foreword by Peter von Sivers'. Salt Lake City: University of Utah Press.

Tibi B. (2000), ,Fundamentalismus im Islam: eine Gefahr für den Weltfrieden?' Darmstadt: Primus.

Tibi B. (2001), 'Islam between culture and politics'. New York: Palgrave, in association with the Weatherhead Center for International Affairs, Harvard University.

Tibi B. (2001), 'Kreuzzug und Djihad. Der Islam und die christliche Welt'. München: Goldmann Taschenbuchausgabe.

Tibi B. (2001), ,Der Islam und Deutschland. Muslime in Deutschland' DVA .

Tibi B. (2002), ,Islamische Zuwanderung: die gescheiterte Integration’ München: Deutsche Verlags-Anstalt.

Tibi B. (2007), ,The Totalitarianism of Jihadist Islamism and its Challenge to Europe and to Islam' Totalitarian Movements and Political Religions, 8, 1, March: 35 - 54.

Troll S.J. Chr. W. (1978), 'Sayyid Ahmad Khan: a reinterpretation of Muslim theology' New Delhi: Vikas Publ. House.

Troll S.J. Chr. W. (2001), ,Der europäische Islam: eine reale Perspektive?’ Berlin: Morus.

Troll S.J. Chr. W. (2001), "Muslime in Deutschland. Ziele, Strömungen, Ogranisationen/Strukturen" http://www.jesuiten.org/aktuell/jubilaeum/files/jahresthema_2001_troll_1.pdf .

Troll S.J. Chr. W. (2003), ,Muslime fragen, Christen antworten’ Dortmund: Topos Plus.

Troll S.J. Chr. W. (2004), ,Als Christ dem Islam begegnen’ Würzburg: Echter. 
Troll S.J. Chr. W. (2007), "Progressives Denken im zeitgenössischen Islam” Friedrich Ebert Stiftung, Islam und Gesellschaft, 4 (entire), available at: .

Troll S.J. Chr. W. and Bsteh A. (Eds.) (1997), 'One world for all: foundations of a socio-political and cultural pluralism from Christian and Muslim perspectives' New Delhi: Vikas Pub. House.

Troll S.J. Chr. W. and Donohue J. (1998), 'Faith, power, and violence: Muslims and Christians in a plural society, past and present' Roma: Pontificio Istituto orientale.

Troll S.J. Chr. W. and Vahiduddin S. (1986), 'Islamic experience in contemporary thought' Delhi: Chanakya Publications.

Weede E. (2006), 'Is there a contradiction between freedom and Islam?' Paper, Department of Sociology, University of Bonn (FRG); available at: http://admin.fnst.org/uploads/896/Weede_engl.pdf . 


\section{Appendix A: List of World Values Survey variables:}

1. mean left-right position

2. not satisfied with democracy

3. openly racist

4. openly anti-Semitic

5. belief in hell

6. only God-believing politicians

7. mean acceptability homosexuality

8. mean acceptance competition

9. secularization rate (never attending rel. Services)

10. always respect parents

11. education for tolerance and respect important

12. never praying

13. thrift important in education

14. mean workaholic scale

15. jobs scarce men have rights

16 . belong voluntary welfare elderly

17. unpaid social welfare work

18. just can't be too careful

19. mean satisfaction income

20. mean acceptance government benefits fraud

21. unpaid work religious organizations

22. for less materialism

23. emphasis on authority good

24 . income differences good

25. government sector

26. Confidence in the EU

27. rejecting foreign workers

28. rejecting homosexual neighbour

29. never occupy building/factory

30. Islamophobia 


\section{Appeendix B: Data sources for the analysis of globalization and value change in world society}

1. Heshmati A. and Tausch A. (Eds.) „Roadmap to Bangalore”? Globalization, the EU's Lisbon Process and the Structures of Global Inequality”. Hauppauge, NY: Nova Science Publishers Inc

2. IMF http://www.imf.org/external/datamapper/index.php

3. UNDP Human Development Report Office http://hdr.undp.org/en/statistics/data/

4. World Values Survey, http://www.worldvaluessurvey.org/ University of Michigan

\begin{tabular}{|c|l|l|l|}
\hline 1 & independent variable & World Values Survey & $\begin{array}{l}\text { traditional values (principal component } \\
\text { analysis from WVS data) }\end{array}$ \\
\hline 2 & independent variable & World Values Survey & $\begin{array}{l}\text { intransparent, inactive (principal component } \\
\text { analysis from WVS data) }\end{array}$ \\
\hline 3 & independent variable & World Values Survey & $\begin{array}{l}\text { "Asabiyya" (principal component analysis } \\
\text { from WVS data) }\end{array}$ \\
\hline 8 & independent variable & World Values Survey & belief in hell \\
\hline 20 & independent variable & World Values Survey & unpaid social welfare work \\
\hline 64 & independent variable & $\begin{array}{l}\text { Kearney/Bhandari/Hesh } \\
\text { mati }\end{array}$ & Kearney Index mid 2000s \\
\hline 70 & independent variable & calculated from UNDP & ln GDP per capita \\
\hline 71 & independent variable & calculated from UNDP & ln GDP per capita $\wedge 2$ \\
\hline 125 & dependent variable & IMF & IMF prediction growth rate in 2009 \\
\hline 126 & dependent variable & IMF & IMF prediction growth rate in 2010 \\
\hline
\end{tabular}




\section{Appendix C: Analysis of WVS data}

Ibn Khaldoun revisited: a principal components analysis of central World Values Survey indicators.

Mean substitution of missing World Values Survey country data values

\begin{tabular}{|c|c|c|c|}
\hline Variable definition & Indicator & Initial & $\begin{array}{l}\text { Extraction (\% of total } \\
\text { variance explained) }\end{array}$ \\
\hline mean left-right position & VAR00001 & 1 & 0,238 \\
\hline not satisfied with democracy & VAR00002 & 1 & 0,405 \\
\hline openly racist & VAR00003 & 1 & 0,501 \\
\hline openly anti-Semitic & VAR00004 & 1 & 0,256 \\
\hline belief in hell & VAR00005 & 1 & 0,681 \\
\hline only God-believing politicians & VAR00006 & 1 & 0,491 \\
\hline mean acceptability homosexuality & VAR00007 & 1 & 0,783 \\
\hline mean acceptance competition & VAR00008 & 1 & 0,228 \\
\hline $\begin{array}{l}\text { secularization rate (never attending } \\
\text { rel. Services) }\end{array}$ & VAR00009 & 1 & 0,245 \\
\hline always respect parents & VAR00010 & 1 & 0,734 \\
\hline $\begin{array}{l}\text { education for tolerance and respect } \\
\text { important }\end{array}$ & VAR00011 & 1 & 0,43 \\
\hline never praying & VAR00012 & 1 & 0,309 \\
\hline thrift important in education & VAR00013 & 1 & 0,141 \\
\hline mean workaholic scale & VAR00014 & 1 & 0,11 \\
\hline jobs scarce men have rights & VAR00015 & 1 & 0,626 \\
\hline belong voluntary welfare elderly & VAR00016 & 1 & 0,41 \\
\hline unpaid social welfare work & VAR00017 & 1 & 0,323 \\
\hline just can't be too careful & VAR00018 & 1 & 0,385 \\
\hline mean satisfaction income & VAR00019 & 1 & 0,138 \\
\hline $\begin{array}{l}\text { mean acceptance government benefits } \\
\text { fraud }\end{array}$ & VAR00020 & 1 & 0,301 \\
\hline cheating taxes & VAR00021 & 1 & 0,516 \\
\hline taking bribes & VAR00022 & 1 & 0,409 \\
\hline unpaid work religious organizations & VAR00023 & 1 & 0,313 \\
\hline for less materialism & VAR00024 & 1 & 0,161 \\
\hline emphasis on authority good & VAR00025 & 1 & 0,213 \\
\hline income differences good & VAR00026 & 1 & 0,127 \\
\hline government sector & VAR00027 & 1 & 0,226 \\
\hline Confidence in the EU & VAR00028 & 1 & 0,157 \\
\hline rejecting foreign workers & VAR00029 & 1 & 0,497 \\
\hline rejecting homosexual neighbour & VAR00030 & 1 & 0,523 \\
\hline never occupy building/factory & VAR00031 & 1 & 0,122 \\
\hline Islamophobia & VAR00032 & 1 & 0,259 \\
\hline
\end{tabular}


The cumulated share of total variance explained by the model

\begin{tabular}{|c|c|c|c|}
\hline & Total & \% of variance & cumulated \% \\
\hline 1 & 7,653 & 23,915 & 23,915 \\
\hline 2 & 3,603 & 11,26 & 35,175 \\
\hline
\end{tabular}

The loadings:

\begin{tabular}{|c|c|c|c|}
\hline & & $\begin{array}{c}\text { traditional versus } \\
\text { secular attitudes }\end{array}$ & $\begin{array}{c}\text { cheating versus } \\
\text { active society }\end{array}$ \\
\hline mean left-right position & VAR00001 & 0,335 & $-0,355$ \\
\hline not satisfied with democracy & VAR00002 & 0,294 & 0,564 \\
\hline openly racist & VAR00003 & 0,651 & $-0,278$ \\
\hline openly anti-Semitic & VAR00004 & 0,498 & 0,092 \\
\hline belief in hell & VAR00005 & 0,805 & $-0,179$ \\
\hline only God-believing politicians & VAR00006 & 0,633 & $-0,301$ \\
\hline mean acceptability homosexuality & VAR00007 & $-0,877$ & $-0,114$ \\
\hline mean acceptance competition & VAR00008 & $-0,385$ & 0,282 \\
\hline $\begin{array}{l}\text { secularization rate (never attending } \\
\text { rel. Services) }\end{array}$ & VAR00009 & $-0,472$ & $-0,147$ \\
\hline always respect parents & VAR00010 & 0,849 & 0,115 \\
\hline $\begin{array}{l}\text { education for tolerance and respect } \\
\text { important }\end{array}$ & VAR00011 & $-0,557$ & $-0,346$ \\
\hline never praying & VAR00012 & $-0,53$ & 0,17 \\
\hline thrift important in education & VAR00013 & 0,26 & 0,27 \\
\hline mean workaholic scale & VAR00014 & 0,327 & $-0,058$ \\
\hline jobs scarce men have rights & VAR00015 & 0,787 & $-0,08$ \\
\hline belong voluntary welfare elderly & VAR00016 & $-0,091$ & $-0,634$ \\
\hline unpaid social welfare work & VAR00017 & 0,194 & $-0,534$ \\
\hline just can't be too careful & VAR00018 & 0,446 & 0,431 \\
\hline mean satisfaction income & VAR00019 & $-0,311$ & $-0,203$ \\
\hline $\begin{array}{l}\text { mean acceptance government } \\
\text { benefits fraud }\end{array}$ & VAR00020 & 0,111 & 0,537 \\
\hline cheating taxes & VAR00021 & $-0,281$ & 0,661 \\
\hline taking bribes & VAR00022 & $-0,02$ & 0,639 \\
\hline unpaid work religious organizations & VAR00023 & 0,365 & $-0,424$ \\
\hline for less materialism & VAR00024 & $-0,399$ & $-0,034$ \\
\hline emphasis on authority good & VAR00025 & 0,416 & $-0,199$ \\
\hline income differences good & VAR00026 & 0,329 & $-0,135$ \\
\hline government sector & VAR00027 & 0,452 & 0,148 \\
\hline Confidence in the EU & VAR00028 & 0,375 & 0,129 \\
\hline rejecting foreign workers & VAR00029 & 0,685 & $-0,168$ \\
\hline rejecting homosexual neighbour & VAR00030 & 0,635 & 0,347 \\
\hline never occupy building/factory & VAR00031 & 0,342 & 0,068 \\
\hline Islamophobia & VAR00032 & 0,382 & 0,336 \\
\hline
\end{tabular}


Factor scores

\begin{tabular}{|c|c|c|c|c|c|}
\hline & traditional & $\begin{array}{c}\text { intranspar } \\
\text { ent, } \\
\text { inactive }\end{array}$ & $\begin{array}{l}\text { predicted } \\
\text { value }\end{array}$ & $\begin{array}{l}\text { bad performance } \\
\text { low transparency } \\
\text { and low activity } \\
\text { even at high } \\
\text { levels of } \\
\text { development) }\end{array}$ & $\begin{array}{c}\text { good } \\
\text { performance }\end{array}$ \\
\hline Viet Nam [2001] & 0,451 & $-2,216$ & 0,325 & $-2,541$ & 2,541 \\
\hline United States [1999] & $-0,666$ & $-1,554$ & 0,364 & $-1,918$ & 1,918 \\
\hline China [2001] & 0,458 & $-1,501$ & 0,321 & $-1,822$ & 1,822 \\
\hline Tanzania, [2001] & 1,286 & $-2,247$ & $-0,512$ & $-1,735$ & 1,735 \\
\hline Canada [2000] & $-1,179$ & $-1,157$ & $-0,033$ & $-1,124$ & 1,124 \\
\hline Iran ( [2000] & 0,542 & $-0,729$ & 0,267 & $-0,996$ & 0,996 \\
\hline Australia [1995] & $-0,937$ & $-0,765$ & 0,187 & $-0,952$ & 0,952 \\
\hline Egypt [2000] & 1,559 & $-1,804$ & $-0,936$ & $-0,868$ & 0,868 \\
\hline Bangladesh [2002] & 2,184 & $-2,993$ & $-2,183$ & $-0,810$ & 0,810 \\
\hline Ireland [1999] & $-0,610$ & $-0,415$ & 0,392 & $-0,807$ & 0,807 \\
\hline Dominican Republic [1996] & 0,231 & $-0,373$ & 0,430 & $-0,803$ & 0,803 \\
\hline Colombia [1998] & 0,133 & $-0,329$ & 0,462 & $-0,791$ & 0,791 \\
\hline Iceland [1999] & $-1,643$ & $-1,349$ & $-0,616$ & $-0,732$ & 0,732 \\
\hline New Zealand [1998] & $-1,123$ & $-0,577$ & 0,023 & $-0,600$ & 0,600 \\
\hline Uruguay [1996] & $-0,842$ & $-0,307$ & 0,257 & $-0,564$ & 0,564 \\
\hline Japan [2000] & $-0,563$ & $-0,139$ & 0,412 & $-0,551$ & 0,551 \\
\hline Israel [2001] & $-0,491$ & $-0,091$ & 0,440 & $-0,530$ & 0,530 \\
\hline Argentina [1999] & $-0,443$ & $-0,055$ & 0,455 & $-0,510$ & 0,510 \\
\hline Iraq [2004] & 0,960 & $-0,599$ & $-0,103$ & $-0,496$ & 0,496 \\
\hline Italy [1999] & $-0,558$ & $-0,077$ & 0,414 & $-0,491$ & 0,491 \\
\hline Morocco [2001] & 1,186 & $-0,852$ & $-0,376$ & $-0,477$ & 0,477 \\
\hline Jordan [2001] & 1,258 & $-0,942$ & $-0,473$ & $-0,470$ & 0,470 \\
\hline Malta [1999] & 0,740 & $-0,345$ & 0,113 & $-0,459$ & 0,459 \\
\hline Singapore [2002] & 0,398 & $-0,093$ & 0,355 & $-0,447$ & 0,447 \\
\hline Uganda [2001] & 0,856 & $-0,425$ & 0,005 & $-0,430$ & 0,430 \\
\hline Venezuela [2000] & 0,576 & $-0,182$ & 0,244 & $-0,425$ & 0,425 \\
\hline Nigeria [2000] & 0,970 & $-0,530$ & $-0,114$ & $-0,416$ & 0,416 \\
\hline Norway [1996] & $-1,405$ & $-0,677$ & $-0,290$ & $-0,386$ & 0,386 \\
\hline Finland [2000] & $-1,355$ & $-0,613$ & $-0,229$ & $-0,384$ & 0,384 \\
\hline Saudi Arabia [2003] & 0,945 & $-0,429$ & $-0,087$ & $-0,343$ & 0,343 \\
\hline Zimbabwe [2001] & 1,212 & $-0,665$ & $-0,410$ & $-0,255$ & 0,255 \\
\hline Austria [1999] & $-0,971$ & $-0,078$ & 0,160 & $-0,238$ & 0,238 \\
\hline Switzerland [1996] & $-1,316$ & $-0,414$ & $-0,183$ & $-0,232$ & 0,232 \\
\hline India [2001] & 0,798 & $-0,163$ & 0,061 & $-0,224$ & 0,224 \\
\hline Great Britain [1999] & $-1,206$ & $-0,265$ & $-0,061$ & $-0,204$ & 0,204 \\
\hline Chile [2000] & $-0,423$ & 0,399 & 0,461 & $-0,062$ & 0,062 \\
\hline Peru [2001] & 0,498 & 0,256 & 0,296 & $-0,040$ & 0,040 \\
\hline Serbia [2001] & $-0,218$ & 0,516 & 0,497 & 0,019 & $-0,019$ \\
\hline Bosnia and Herzegovina [2001] & 0,316 & 0,421 & 0,395 & 0,025 & $-0,025$ \\
\hline Mexico [2000] & 0,387 & 0,403 & 0,361 & 0,042 & $-0,042$ \\
\hline Sweden [1999] & $-2,120$ & $-1,371$ & $-1,439$ & 0,068 & $-0,068$ \\
\hline El Salvador [1999] & 0,868 & 0,063 & $-0,007$ & 0,070 & $-0,070$ \\
\hline Poland [1999] & 0,259 & 0,491 & 0,420 & 0,071 & $-0,071$ \\
\hline Czech Republic [1999] & $-0,993$ & 0,224 & 0,141 & 0,082 & $-0,082$ \\
\hline Croatia [1999] & $-0,075$ & 0,583 & 0,497 & 0,086 & $-0,086$ \\
\hline Bulgaria [1999] & 0,141 & 0,552 & 0,460 & 0,093 & $-0,093$ \\
\hline Portugal [1999] & $-0,573$ & 0,503 & 0,408 & 0,095 & $-0,095$ \\
\hline
\end{tabular}




\begin{tabular}{|l|c|c|c|c|c|}
\hline Spain [2000] & $-1,011$ & 0,228 & 0,126 & 0,102 & $-0,102$ \\
\hline Indonesia [2001] & 1,320 & $-0,455$ & $-0,561$ & 0,106 & $-0,106$ \\
\hline South Africa [2001] & 0,743 & 0,218 & 0,110 & 0,108 & $-0,108$ \\
\hline Latvia [1999] & $-0,398$ & 0,592 & 0,467 & 0,124 & $-0,124$ \\
\hline Germany West [1999] & $-1,380$ & $-0,112$ & $-0,260$ & 0,148 & $-0,148$ \\
\hline Pakistan [2001] & 1,223 & $-0,164$ & $-0,425$ & 0,261 & $-0,261$ \\
\hline Slovenia [1999] & $-0,661$ & 0,628 & 0,366 & 0,261 & $-0,261$ \\
\hline Algeria [2002] & 1,452 & $-0,491$ & $-0,761$ & 0,270 & $-0,270$ \\
\hline Luxembourg [1999] & $-1,233$ & 0,223 & $-0,090$ & 0,312 & $-0,312$ \\
\hline Hungary [1999] & $-0,152$ & 0,826 & 0,500 & 0,327 & $-0,327$ \\
\hline Kyrgyzstan [2003] & 0,564 & 0,694 & 0,252 & 0,442 & $-0,442$ \\
\hline Denmark [1999] & $-2,153$ & $-1,026$ & $-1,504$ & 0,478 & $-0,478$ \\
\hline Slovakia [1999] & $-0,065$ & 1,004 & 0,497 & 0,507 & $-0,507$ \\
\hline Republic of Korea [2001] & 1,066 & 0,299 & $-0,224$ & 0,523 & $-0,523$ \\
\hline Albania [2002] & 0,982 & 0,433 & $-0,128$ & 0,560 & $-0,560$ \\
\hline Macedonia [2001] & 0,549 & 0,828 & 0,263 & 0,565 & $-0,565$ \\
\hline Belgium [1999] & $-1,232$ & 0,493 & $-0,089$ & 0,582 & $-0,582$ \\
\hline Romania [1999] & 0,740 & 0,734 & 0,114 & 0,621 & $-0,621$ \\
\hline Netherlands [1999] & $-2,379$ & $-1,336$ & $-1,981$ & 0,645 & $-0,645$ \\
\hline Greece [1999] & $-0,757$ & 1,027 & 0,312 & 0,714 & $-0,714$ \\
\hline Estonia [1999] & $-0,626$ & 1,187 & 0,384 & 0,803 & $-0,803$ \\
\hline Georgia [1996] & 0,905 & 0,831 & $-0,044$ & 0,875 & $-0,875$ \\
\hline Philippines [2001] & 1,061 & 0,745 & $-0,218$ & 0,964 & $-0,964$ \\
\hline Azerbaijan [1997] & 0,610 & 1,192 & 0,219 & 0,973 & $-0,973$ \\
\hline Brazil [1997] & 0,073 & 1,594 & 0,477 & 1,117 & $-1,117$ \\
\hline Russian Federation [1999] & $-0,257$ & 1,743 & 0,493 & 1,250 & $-1,250$ \\
\hline Ukraine [1999] & 0,084 & 1,757 & 0,474 & 1,283 & $-1,283$ \\
\hline Turkey [2001] & 1,464 & 0,523 & $-0,780$ & 1,303 & $-1,303$ \\
\hline Lithuania [1999] & 0,098 & 1,816 & 0,471 & 1,345 & $-1,345$ \\
\hline France [1999] & $-1,603$ & 0,799 & $-0,558$ & 1,357 & $-1,357$ \\
\hline Belarus [2000] & $-0,218$ & 1,973 & 0,497 & 1,476 & $-1,476$ \\
\hline Armenia [1997] & 0,780 & 1,664 & 0,078 & 1,586 & $-1,586$ \\
\hline Republic of Moldova [2002] & 0,909 & 2,443 & $-0,048$ & 2,492 & $-2,492$ \\
\hline & & & & & \\
\hline & & & & \\
\hline
\end{tabular}

